\title{
Greenhouse gas relationships in the Indian summer monsoon plume measured by the CARIBIC passenger aircraft
}

\author{
T. J. Schuck ${ }^{1}$, C. A. M. Brenninkmeijer ${ }^{1}$, A. K. Baker ${ }^{1}$, F. Slemr ${ }^{1}$, P. F. J. von Velthoven ${ }^{2}$, and A. Zahn ${ }^{3}$ \\ ${ }^{1}$ Atmospheric Chemistry Division, Max Planck Institute for Chemistry, Mainz, Germany \\ ${ }^{2}$ Royal Netherlands Meteorological Institute, de Bilt, The Netherlands \\ ${ }^{3}$ Institute for Meteorology and Climate Research, Karlsruhe Institute of Technology, Karlsruhe, Germany
}

Received: 7 January 2010 - Published in Atmos. Chem. Phys. Discuss.: 1 February 2010

Revised: 12 April 2010 - Accepted: 14 April 2010 - Published: 27 April 2010

\begin{abstract}
During the Indian summer monsoon period 2008, regular measurement flights were performed by the CARIBIC aircraft between Germany and India. Measurements included whole air sampling and subsequent analysis for greenhouse gases $\left(\mathrm{CH}_{4}, \mathrm{CO}_{2}, \mathrm{~N}_{2} \mathrm{O}, \mathrm{SF}_{6}\right)$ and in-situ measurements of $\mathrm{CO}, \mathrm{O}_{3}$, and $\mathrm{H}_{2} \mathrm{O}$. For all these tracers a distinct monsoon signature was observed in the longitude range 50$80^{\circ} \mathrm{E}$ south of $40^{\circ} \mathrm{N}$ at flight altitudes $8-12.5 \mathrm{~km}$. The formation of a monsoon plume with enhanced mixing ratios was observed for $\mathrm{CH}_{4}, \mathrm{~N}_{2} \mathrm{O}, \mathrm{SF}_{6}, \mathrm{CO}$ and $\mathrm{H}_{2} \mathrm{O}$. The plume began to develop in May and persisted through September, and maximum mixing ratios and maximum spatial extension of the plume were observed in August. For $\mathrm{CO}_{2}$ and $\mathrm{O}_{3}$ a minimum was observed. The amplitude of the $\mathrm{CO}_{2}$ seasonal cycle was larger than at comparable latitudes outside the monsoon region, and the $\mathrm{CO}_{2}$ spring maximum was observed with a delay of one month. Different tracer relationships show strong spatial variations across the plume. The comparison with NOAA ground station data shows a clear enhancement for $\mathrm{CH}_{4}, \mathrm{~N}_{2} \mathrm{O}, \mathrm{SF}_{6}$ and $\mathrm{CO}$ and a decrease in $\mathrm{CO}_{2}$ mixing ratios. Assuming seasonally invariant $\mathrm{SF}_{6}$ emissions based on the EDGAR 4.0 inventory, monthly emissions were estimated for the period June-September for $\mathrm{CH}_{4}, \mathrm{~N}_{2} \mathrm{O}$, and $\mathrm{CO}$, and the $\mathrm{CO}_{2}$ uptake was estimated. While for $\mathrm{N}_{2} \mathrm{O}$ an emission decrease during the monsoon period was derived, emissions of $\mathrm{CH}_{4}$ were highest in September indicating a different seasonal cycle of emissions. Net $\mathrm{CO}_{2}$ uptake by the vegetation was largest in September.
\end{abstract}

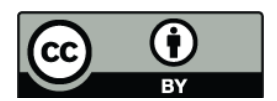

Correspondence to: T. J. Schuck (tanja.schuck@mpic.de)

\section{Introduction}

The Asian monsoon is a major meteorological phenomenon during northern hemisphere summer. The temperature differences between the Asian landmass, especially the Tibetan Plateau, and the Indian Ocean, drive a cyclonic circulation over the Indian Ocean at low altitudes (Hoskins and Rodwell, 1995; Hsu et al., 1999). At the same time, during the summer monsoon period an anticyclone develops in the upper troposphere (Krishnamurti and Bhalme, 1976). Recently, a model study investigated the role of the Tibetan plateau and the high band of the Himalayan mountains for the development of this monsoon circulation (Boos and Kuang, 2010).

The summer monsoon, and thus the rainy season, typically reaches southern India in early June, and it usually starts to retreat at the beginning of September (IMD, 2008; Joseph et al., 2006; Wang et al., 2009). The monsoon circulation not only profoundly influences the large scale dynamics of the lower and upper troposphere, but it also is accompanied by enhanced troposphere-stratosphere exchange (Chen, 1995; Traub and Lelieveld, 2003; Fu et al., 2006; Krishnamurti et al., 2008). Model calculations combined with satellite measurements suggest that the monsoon convection and subsequent transport through the upper-level anticyclone moistens the stratosphere (Lelieveld et al., 2007). This mechanism may also be responsible for transport of pollution into the stratosphere (Randel et al., 2010).

During the summer monsoon, strong and widespread convection occurs over India, the Bay of Bengal and over the Tibetan Plateau, partly over densely populated regions where strong emission sources are located. Surface air masses with enhanced levels of $\mathrm{H}_{2} \mathrm{O}, \mathrm{CO}$, and many other trace gases are lifted and subsequently mixed into the large-scale circulation. The rapid convective vertical transport of polluted boundary layer air thus leads to enhanced mixing ratios of many trace gases in the upper-level anticyclone. 
In addition, the intense precipitation associated with the summer monsoon affects the activity of several sources. For instance, $\mathrm{CH}_{4}$ emissions from wetlands and rice paddies increase, $\mathrm{CO}_{2}$ uptake by plants increases, while $\mathrm{CO}$ emissions from wildfires and agricultural waste burning are expected to decrease. The monsoon meteorology therefore not only influences the dynamics of the upper troposphere, it also affects its chemical composition. Air masses carrying a distinct monsoon signature such as enrichment of $\mathrm{CH}_{4}$ can accumulate in the anticyclone, leading to the formation of a localized maximum that persists throughout the summer. In the following, the word "plume" denotes this large, quasi-stationary feature of polluted air.

Satellite observations reveal strong seasonal variations of various tracers in the anticyclone. High summer time mixing ratios over South Asia were reported for $\mathrm{CO}$ (Fu et al., 2006; Park et al., 2008), for $\mathrm{H}_{2} \mathrm{O}$ (Park et al., 2004; Fu et al., 2006; Randel and Park, 2006), and for $\mathrm{CH}_{4}$ (Park et al., 2004; Schneising et al., 2009; Xiong et al., 2009). Other trace gases that were observed to be enhanced in the monsoon region included $\mathrm{NO}_{\mathrm{x}}$ (Park et al., 2004), $\mathrm{HCN}, \mathrm{C}_{2} \mathrm{H}_{6}$, and $\mathrm{C}_{2} \mathrm{H}_{2}$ (Park et al., 2008). In addition, a concomitant decrease of $\mathrm{O}_{3}$ was observed (Randel and Park, 2006; Liu et al., 2009)). These observations were explained to be due to convective uplifting of boundary layer air in the monsoon region (Randel and Park, 2006) and were shown to be in agreement with model results, for example from the MOZART model. Simulations predicted high mixing ratios of $\mathrm{CH}_{4}$ in the anticyclone between $60^{\circ} \mathrm{E}$ and $120^{\circ} \mathrm{E}$ around $30^{\circ} \mathrm{N}$ at pressure altitudes between 300 and $100 \mathrm{hPa}$, as well as elevated levels of $\mathrm{H}_{2} \mathrm{O}$ and $\mathrm{NO}_{\mathrm{x}}$, in accordance with observations from the HALOE instrument (Park et al., 2004). The model also calculated a $\mathrm{CO}$ maximum at $\sim 15 \mathrm{~km}$ altitude, in agreement with MLS and ACE-FTS measurements (Park et al., 2009). Moreover, calculations using the TM3 model generally agree with the observation of elevated $\mathrm{CH}_{4}$ mixing ratios, although the plume position reproduced from the model is somewhat different from the AIRS observation. Satellite instruments, despite their limited vertical resolution, can also provide information on the altitude range of the observed tracer enhancements. The observed monsoon plume in $\mathrm{CH}_{4}$ is for example reported by the AIRS instrument to be situated in the altitude interval from $500 \mathrm{hPa}$ to $150 \mathrm{hPa}$ (Xiong et al., 2009), the MOZART model predicts a vertical extension from $\sim 300-150 \mathrm{hPa}$ (Park et al., 2004).

Strong variations during the summer monsoon period are also expected for $\mathrm{CO}_{2}$ with its pronounced seasonal cycle related to photosynthesis and respiration. The drop in boundary layer concentrations for this greenhouse gas should be reflected by upper tropospheric levels due to rapid and widespread convective transport. Signatures of the Asian monsoon in upper tropospheric $\mathrm{CO}_{2}$ have indeed been observed, e.g. by the IASI satellite instrument (Crevoisier et al., 2009). However, most studies based on $\mathrm{CO}_{2}$ measurements by satellites concentrated on different aspects of the $\mathrm{CO}_{2}$ dis- tribution, mainly taking a more global approach or focusing on highly industrialized regions rather than the Asian monsoon region (e.g. Chédin et al., 2003; Buchwitz et al., 2007a,b; Schneising et al., 2008).

Although an increasing number of satellite remote sensing observations of various trace gases is becoming available, systematic in-situ measurements of the composition of the upper troposphere are scarce in the areas most influenced by the Asian summer monsoon. Most studies investigating the influence of the monsoon circulation, such as the Arabian Sea Monsoon Experiment or the Bay of Bengal Monsoon Experiment (Sanjeeva Rao, 2005; Bhat and Narashima, 2007), involved ground and ship based measurements but no in-situ measurements in the upper troposphere. The Indian Ocean Experiment (INDOEX) did include aircraft measurements, but investigated the transport of pollution over the Indian Ocean in winter (Lelieveld et al., 2001). The Mediterranean Intensive Oxidant Study (MINOS) captured the outflow of pollutants from the monsoon anticyclone and their westward transport. It was shown that the upper troposphere over the Mediterranean was strongly influenced by long-range transport from the monsoon region (Lelieveld et al., 2002; Scheeren et al., 2003).

To study the influence of the Indian summer monsoon on the composition of the upper troposphere, not only over the Indian Ocean but also over land, 16 flights with the CARIBIC (Civil Aircraft for the Regular Investigation of the Atmosphere Based on an Instrument Container, www.caribicatmospheric.com) aircraft took place between Frankfurt, Germany, and Chennai, India, from April to December 2008. Next to $\mathrm{CH}_{4}$ and $\mathrm{CO}_{2}$, two other greenhouse gases, $\mathrm{N}_{2} \mathrm{O}$ and $\mathrm{SF}_{6}$ will be discussed. $\mathrm{SF}_{6}$, an entirely anthropogenic gas, can be used as a tracer to estimate the emissions of the other greenhouses gases during the monsoon time. Further tracers measured are $\mathrm{CO}$ which, compared to the aforementioned greenhouse gases, has a short lifetime and $\mathrm{H}_{2} \mathrm{O}$ and $\mathrm{O}_{3}$, which show a very different behavior in the monsoon plume.

\section{Technical and analytical details}

CARIBIC is a long-term atmospheric measurement program. It is based on the use of a fully automated scientific instrument package in a $1.5 \mathrm{t}$ container aboard a passenger aircraft which is equipped with an advanced multi-probe inlet system (Brenninkmeijer et al., 2007). The present CARIBIC system came into service in December 2004, and since then it is operated monthly aboard a Lufthansa Airbus A340-600 passenger aircraft. With typical cruising altitudes ranging from 8.5 to $12 \mathrm{~km}$ (corresponding to $300-180 \mathrm{hPa}$ ), the CARIBIC aircraft frequently crosses the tropopause at mid-latitudes. At low latitudes the free tropical troposphere is probed. Figure 1 shows the CARIBIC flight tracks between Frankfurt $\left(50.03^{\circ} \mathrm{N}, 8.54^{\circ} \mathrm{E}\right)$ and Chennai $\left(12.99^{\circ} \mathrm{N}, 80.18^{\circ} \mathrm{E}\right)$ in 


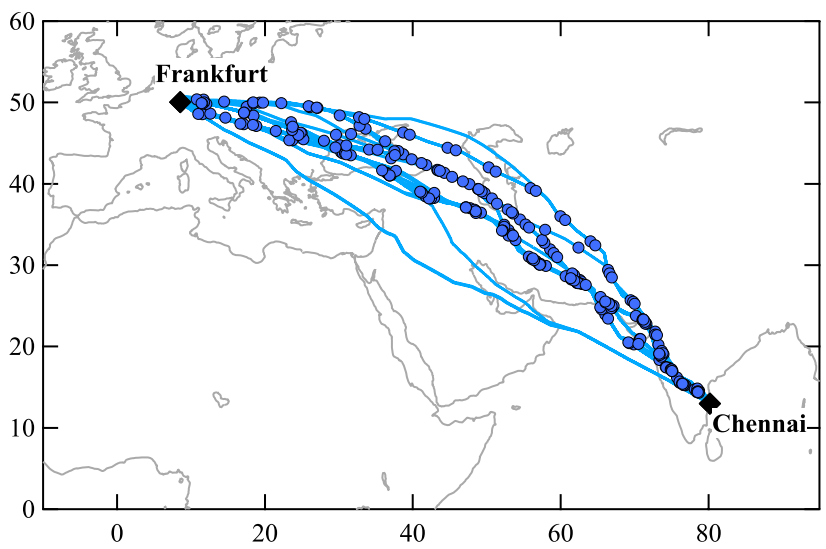

Fig. 1. CARIBIC flights between Germany and India in 2008 . Shown are the flight routes for 16 round trips between Frankfurt and Chennai from April to December 2008. On 9 round trips air samples were taken at the positions indicated.

2008. Flights were performed monthly April through December. Usually one set of flights consisted of four consecutive flights, i.e. two round trips from Frankfurt to Chennai within three days, with exception of July and October, when only one round trip was performed.

The CARIBIC instrument container houses a range of insitu trace gas and aerosol analyzers, complemented by an aerosol sampler and a whole air sample collection system (Brenninkmeijer et al., 2007). The latter comprises a pumping unit and two separate sampling units, each containing 14 glass cylinders with a volume of 2.671 . Depending on the flight altitude, the total sample collection times range from 30 to $90 \mathrm{~s}$, corresponding to a spatial resolution of about 7 to $21 \mathrm{~km}$. Depending on the flight altitude, the air sample volume ranges from 9 to 111 (STP). In order to get a higher spatial coverage along the flight track, given the number of samples carried aboard being limited to 28, sampling took always place during only the first round trip Frankfurt-Chennai, with 14 samples being filled on the first outbound flight and 14 samples on the corresponding return flight. Samples were taken at even time steps with on average one sample per half hour. In total, 251 whole air samples were collected during the 16 long-distance flights. After returning from the final flight leg, the container is de-installed from the aircraft. Subsequently, the sample units are removed and the pressurized samples are analyzed in several laboratories. The standard greenhouse gas analysis is performed for all samples as soon as possible, usually within two days after the last flight. Briefly, it comprises simultaneous measurements using a HP 6890 gas chromatograph of $\mathrm{CH}_{4}$ and $\mathrm{CO}_{2}$ with a flame ionization detector (FID) and of $\mathrm{N}_{2} \mathrm{O}$ and $\mathrm{SF}_{6}$ with an electron capture detector (ECD) (Schuck et al., 2009). The average precision obtained for the flights between Frankfurt and Chennai in 2008 is $0.12 \%$ for $\mathrm{CH}_{4}, 0.07 \%$ for $\mathrm{CO}_{2}$,
$0.11 \%$ for $\mathrm{N}_{2} \mathrm{O}$, and $0.9 \%$ for $\mathrm{SF}_{6}$. Calibration is based on seven standard gas mixtures acquired from NOAA-ESRL. To calculate mixing ratios in dry air, the continuously measured total water mixing ratio is used for correction.

A description of all instruments of the CARIBIC container and the inlet system is given in (Brenninkmeijer et al., 2007). The package comprises several in-situ instruments for online measurements of various trace gases, among them $\mathrm{CO}$, $\mathrm{O}_{3}$, and $\mathrm{H}_{2} \mathrm{O}$. The air flow for measurements of $\mathrm{CO}$ and $\mathrm{O}_{3}$ is through the same sampling line used for the collection of whole air samples with sampling perpendicular to the flight direction. $\mathrm{CO}$ is measured using a vacuum ultraviolet fluorescence instrument that is operated with a time resolution of $1 \mathrm{~s}$ and is calibrated in flight every $25 \mathrm{~min}$. The uncertainty estimated from the propagation of the uncertainties of calibration gas and the standard deviations of the measurement, zero, and calibration signals is typically $1.9 \%$ or 1 ppbv, whichever is greater. $\mathrm{O}_{3}$ is measured using a dualbeam UV-photometer with a time resolution of $4 \mathrm{~s}$. Comparisons with a laboratory standard showed that at a time resolution of $4 \mathrm{~s}$ a precision of $0.3 \mathrm{ppbv}$ (or $0.3 \%$, whatever is highest) and a total uncertainty of $\sim 1.5 \%$ can be achieved.

For measurements of $\mathrm{H}_{2} \mathrm{O}$ two instruments are used, a commercial chilled mirror frost point hygrometer (CR2, Buck Research, total uncertainty $0.5 \mathrm{~K}$, time resolution 30 $300 \mathrm{~s}$ ) and a fast two-channel photo-acoustic laser spectrometer (precision $0.5 \mathrm{ppmv}$, time resolution 5-10 s), using laser light to excite water molecules and measuring their thermal relaxation. Two separate sampling lines are used to allow for measurements of gaseous and condensed water. Both instruments are supplied with air from an inlet facing flight direction for the detection of both, gaseous and condensed water including ice particles (total water). The total water mixing ratio is used for the calculation of greenhouse gas mixing ratios in dry air. In addition, the second channel of the photo acoustic detector is connected to an orifice perpendicular to the flight direction for the detection of water vapor only.

The position and selected meteorological data recorded by the aircraft systems are provided to the CARIBIC master computer with a time resolution of $1 \mathrm{~s}$. The master computer also records signals from different pressure and temperature sensors in the container and the inlet probe, and it communicates with the instruments via an Ethernet network, activating and de-activating them and continuously monitoring their status during a flight. To avoid sampling of polluted air in the vicinity of airports, measurements only take place at outside pressures below $650 \mathrm{hPa}$. Eventually, all data are reported in terms of the time signal from the master computer.

The routinely produced meteorological plots and trajectory calculations for each flight are based on meteorological analysis data from the European Centre for Medium range Weather Forecasts (ECMWF) (van Velthoven, 2009). Trajectories are calculated 5 days backward with the KNMI trajectory model TRAJKS (Scheele et al., 1996) for every 3 min of flight. For the trajectory calculations global gridded 
ECMWF wind fields with a horizontal resolution of $1^{\circ} \times 1^{\circ}$ at time intervals of 6 hours were used. Additionally, 8-day trajectories are calculated for every 6 seconds of flight during the collection time of each whole air sample. The ECMWF data themselves were also interpolated to the 3-D-location and time of the aircraft for every minute of flight for comparison with the measurements. They were then slightly further interpolated to meet the $10 \mathrm{~s}$-averages of the merged observational data, and they were integrated in the same way as the continuous measurements over the sampling period of the flask samples.

\section{Meteorology}

In the upper troposphere, the Asian summer monsoon is associated with an anticyclone that forms in April over Southeast Asia at equatorial latitudes. In summer, this anticyclone drifts northwestward, eventually reaching the Tibetan Plateau around $20-30^{\circ} \mathrm{N}$ (Krishnamurti and Bhalme, 1976; Hsu et al., 1999). In parallel, the westerly subtropical jet weakens in spring and shifts to more northern latitudes while a weak easterly jet develops at latitudes around $10^{\circ} \mathrm{N}(\mathrm{Kr}-$ ishnamurti et al., 2008). This easterly jet is a possible pathway for transport of pollution uplifted by convection from South Asia towards Northern Africa and the Mediterranean through the subsequent transport by the Arabian anticyclone (Lelieveld et al., 2002). Most summer rainfall occurs on the northern side of this easterly jet (Krishnamurti et al., 2008). During the dry season, rainfall occurs mainly south of $10^{\circ} \mathrm{N}$ (Krishnamurti et al., 1997).

The monsoon anticyclone is bordered by the westerly jet on its northern flank and in the south by the weaker easterly jet. Measurements of the zonal wind speed can be used as an indicator for the location and drift of the anticyclone. Therefore, of the observables that are recorded by the CARIBIC system, the horizontal wind speed is the one best suited to characterize the meteorological situation during a flight and to follow the seasonal changes. Figure 2 shows the westerly component of the horizontal wind speed averaged over $10 \mathrm{~s}$ intervals as a function of latitude for the flights to and from Chennai in 2008. The latitudinal variation of the zonal wind speed shows distinct changes throughout the year and can be used to identify the summer monsoon months. Panel a shows the distribution of the wind speed in summer from June through September. Maximum westerly wind speeds (positive numbers) are recorded north of $\sim 35^{\circ} \mathrm{N}$ with values around $40 \mathrm{~m} / \mathrm{s}$. There is no localized maximum of the wind speed, but rather a plateau in the latitudinal distribution. South of $25^{\circ} \mathrm{N}$, easterly winds (negative numbers) with speeds up to $30 \mathrm{~m} / \mathrm{s}$ are observed. Maximum wind speeds of the tropical easterly jet are around $35 \mathrm{~m} / \mathrm{s}$ at pressure altitudes around $175 \mathrm{hPa}$ (Krishnamurti et al., 2008). The CARIBIC aircraft cruises at altitudes around $300-200 \mathrm{hPa}$, thus crossing the lower part this easterly jet, where maxi-

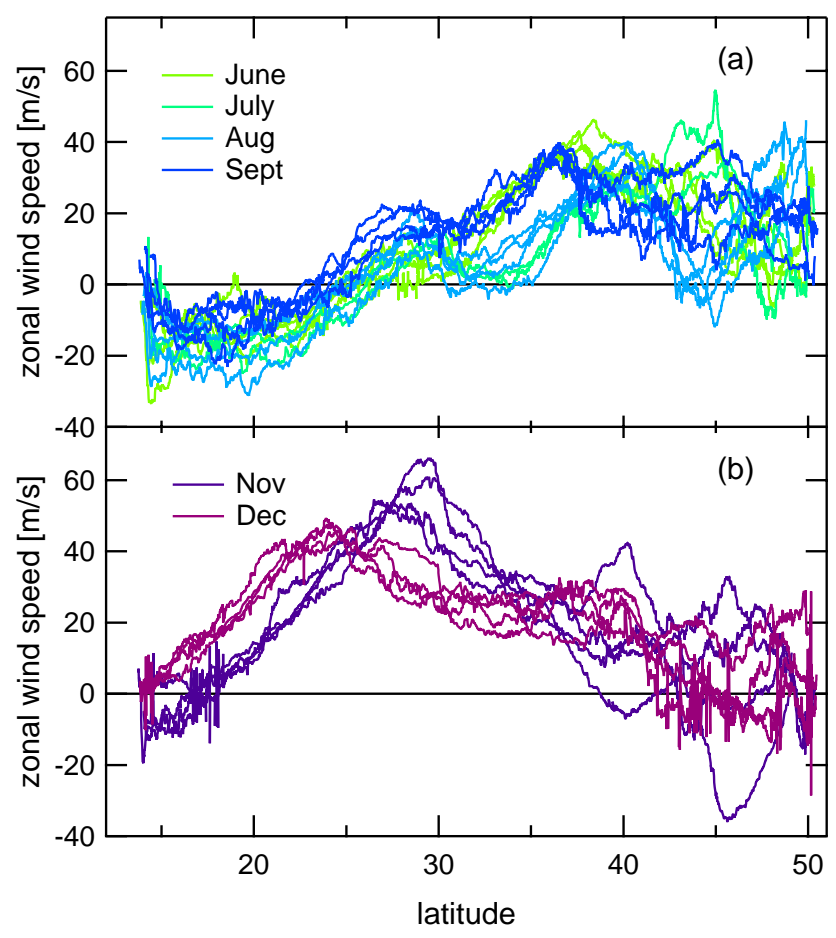

Fig. 2. Zonal wind speed as a function of latitude observed during CARIBIC flights to India in summer and winter 2008. Spring and autumn months are not shown. Positive wind speeds indicate westerly flows, negative wind speeds easterly flows.

mum wind speeds are lower. Figure 3 shows a pressure level map of the wind speed at $250 \mathrm{hPa}$ based on ECMWF data for the flight from Frankfurt to Chennai on August 13th. The cruise altitude during this flight varied between $\sim 240 \mathrm{hPa}$ and $\sim 215 \mathrm{hPa}$. Clearly discernible are the large scale anticyclonic circulation, the easterly jet south of $20^{\circ} \mathrm{N}$, and the westerly jet around $40^{\circ} \mathrm{N}$.

Panel b of Fig. 2 shows the wind speed for November and December 2008. The westerly jet now extends further south and a pronounced maximum of the wind speed is observed around $25-30^{\circ} \mathrm{N}$, with maximum values of $60 \mathrm{~m} / \mathrm{s}$ in December. Similar latitudinal distributions were observed during flights between Germany and the Philippines via China in winter. Not shown are the flights that took place in April, May and October. During these transition months, wind speeds are lower than in winter, comparable to the maximum levels in summer. The latitudinal distribution does not show a clear maximum and no tropical easterly jet was present in the latitude range $10-40^{\circ} \mathrm{N}$. Studying the behavior of the horizontal wind speed as a function of latitude for all flights to India and to the Philippines for three years (2006-2008) shows that the common seasonal classification scheme according to month may not be appropriate because the transition between the summer and the winter mode does not happen at the same time each year. These differences reflect the 


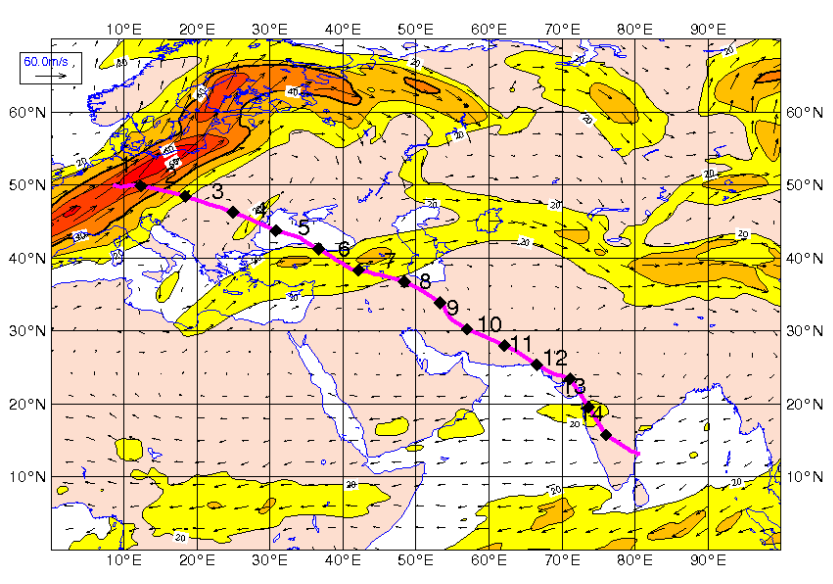

Fig. 3. Wind speed at $250 \mathrm{hPa}$ on August 13th 2008 for a CARIBIC flight from Germany to India. Contours and coloring are in steps of $10 \mathrm{~m} / \mathrm{s}$ for wind speeds between $20 \mathrm{~m} / \mathrm{s}$ and $70 \mathrm{~m} / \mathrm{s}$. The CARIBIC flight path is indicated by the solid line, markers show the positions where air samples were collected.

interannual variations of the upper tropospheric circulation and the varying onset times of the summer monsoon.

Generally, the rainfall season in India is expected to last from 1 June to 30 September (Joseph et al., 2006; Wang et al., 2009). In 2008, the onset of the monsoon rains over southern India was on 31 May, and they progressed north slightly faster than usual. Overall, average amounts of rain were reported by the India Meteorological Department for the whole season, but with large variations. After a rain surplus in June, a rain deficiency was observed in July followed by average rainfall in August and September, and large spatial variations were observed. In 2008, the monsoon started to retreat in September, somewhat later than the long term average (IMD, 2008). Consequently, the features of the summer monsoon meteorology, namely the easterly winds at latitudes around $15-25^{\circ} \mathrm{N}$ are still observed during the CARIBIC flights on 10 th and 11th of September, and in the present analysis September is considered a summer month.

\section{Measurements in the monsoon plume}

\subsection{The $\mathrm{CH}_{4}$ plume}

The most prominent feature observed in trace gas mixing ratios during the flights between Germany and India is the enhancement in upper tropospheric methane mixing ratios during summer. Figure 4 shows the latitudinal distribution of $\mathrm{CH}_{4}$ for spring (April and May), summer (June to September) and autumn (October). The seasons were classified according to the zonal wind speed as described in the previous section. Shown are all tropospheric samples that were collected south of $40^{\circ} \mathrm{N}$. Whereas the CARIBIC aircraft is always in the troposphere at trop-

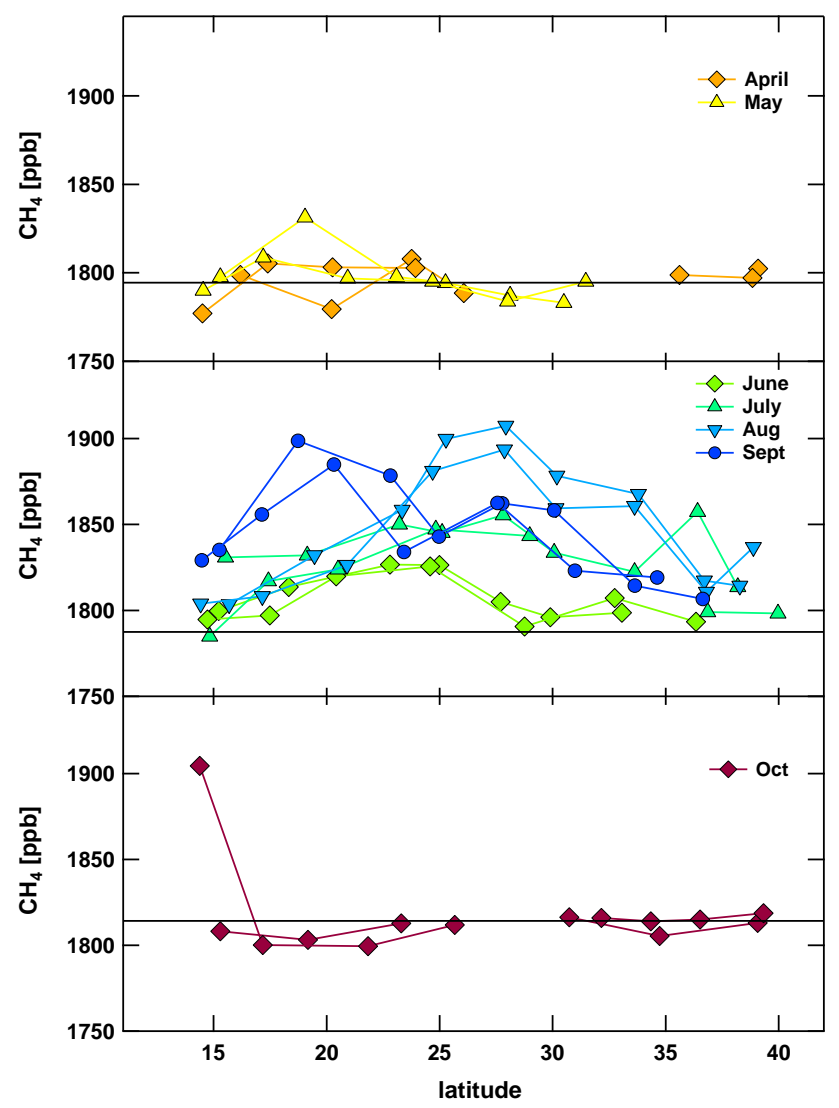

Fig. 4. Mixing ratios of $\mathrm{CH}_{4}$ as a function of latitude for flights between Frankfurt and Chennai from April to October 2008. The horizontal lines indicate the respective mean mixing ratio observed at Mauna Loa Observatory $\left(19^{\circ} \mathrm{N}\right)$.

ical latitudes, it frequently crosses the tropopause in the mid-latitudes. Here, the selection of tropospheric samples is based on potential vorticity by excluding PV values $>1.3$ PVU $\left(1 \mathrm{PVU} \hat{=} 10^{-6} \mathrm{~km}^{2} \mathrm{~kg}^{-1} \mathrm{~s}^{-1}\right)$. Excluded are 19 samples, all collected north of $25^{\circ} \mathrm{N}$ in spring and autumn and north of $30^{\circ} \mathrm{N}$ in summer. The total number of tropospheric samples collected south of $40^{\circ} \mathrm{N}$ is 96 . Included for comparison is the monthly average $\mathrm{CH}_{4}$ mixing ratio observed in the corresponding period at the Mauna Loa Observatory (MLO, $19^{\circ} \mathrm{N}, 155^{\circ} \mathrm{W}, 3397 \mathrm{~m}$ a.s.l.) (Dlugokencky et al., 2009). This station has been chosen because it is a high altitude station, situated in the latitude band where the monsoon plume is observed, but not in a region influenced by direct emissions and monsoon circulations.

In April and May (upper panel), little latitudinal structure is observed, and the values on average agree with those at MLO. Nonetheless, a small relative enhancement is visible around $20^{\circ} \mathrm{N}$, whereas around $30^{\circ} \mathrm{N}$ mixing ratios are slightly lower. In summer (middle panel), the development of a pronounced $\mathrm{CH}_{4}$ plume can be seen. In June, values north of $30^{\circ} \mathrm{N}$ are still at the background level, whereas 
south of $30^{\circ} \mathrm{N}$ an enhancement of up to $\sim 35 \mathrm{ppb}$ occurs. This plume grows in July and August when it extends further north and reaches a maximum value of $1907.4 \pm 2.2 \mathrm{ppb}$ in August around $28^{\circ} \mathrm{N}, 112.8 \mathrm{ppb}$ above the mean value of $1794.6 \mathrm{ppb}$ observed at MLO in August. This amplitude agrees with that of $\sim 100 \mathrm{ppb}$ observed by the AIRS satellite instrument (cf. Fig. 4 in (Xiong et al., 2009)). In September, the maximum $\mathrm{CH}_{4}$ mixing ratios remain high, but are observed at lower latitudes than in August as the plume weakens at its northern end. This southward shift reflects the retreat of the monsoon.

In October (lower panel), the latitudinal distribution of the $\mathrm{CH}_{4}$ mixing ratio has returned to the background level with a weak latitudinal gradient except for the first sample collected after the departure from Chennai on 15 October. This sample was collected during the ascent at an altitude of $8.6 \mathrm{~km}$, while all other samples on the two flights in October were collected at cruise altitudes above $10 \mathrm{~km}$. Backward trajectories indicate that for this flight section the air mass had crossed eastern India at pressure altitudes below $400 \mathrm{hPa}$ implying a high likelihood of urban pollution in the sample. The trajectories for the neighboring samples had been above $400 \mathrm{hPa}$ for at least $24 \mathrm{~h}$ prior to sampling. The low altitude sample also had an exceptionally high water vapor content of $\sim 2300$ ppmv compared to $120-160$ ppmv measured for the neighboring samples and the corresponding sample on the inbound flight.

Figure 5 compares the latitudinal distribution of $\mathrm{CH}_{4}$ for the summer months with that of $\mathrm{N}_{2} \mathrm{O}, \mathrm{SF}_{6}, \mathrm{CO}_{2}$, and $\mathrm{CO}$. $\mathrm{N}_{2} \mathrm{O}$ and $\mathrm{CO}$ show a similar behavior, and their latitudinal distribution closely resembles that of $\mathrm{CH}_{4}$. For both gases the monsoon plume is observed between $15^{\circ} \mathrm{N}$ and $40^{\circ} \mathrm{N}$ in June, and the latitude at which their maximum values are observed shifts northward between June and August, and southward again in September. In parallel, a broadening of the plume can be seen. $\mathrm{SF}_{6}$ also shows an increase throughout summer. Due to the larger relative analytical uncertainty, its latitudinal variation is less apparent than for $\mathrm{CH}_{4}$ and $\mathrm{N}_{2} \mathrm{O}$, but the southward shift from August to September is also observed (cf. Figs. 7, 8). The distributions of $\mathrm{N}_{2} \mathrm{O}, \mathrm{SF}_{6}$, and $\mathrm{CO}$ that are similar to that of $\mathrm{CH}_{4}$ will be discussed in more detail in Sect. 5.

\subsection{Formation of a $\mathrm{CO}_{2}$ minimum}

For $\mathrm{CO}_{2}$, instead of the formation of a plume, the development of a minimum is observed. In June, the distribution looks very similar to that of $\mathrm{CH}_{4}$, with a plume-like structure south of $30^{\circ} \mathrm{N}$. Around $20-25^{\circ} \mathrm{N}$, the CARIBIC measurement is more than $1 \mathrm{ppm}$ higher than the corresponding monthly mean value of $388.35 \mathrm{ppm}$ observed at MLO. This indicates that surface level values of $\mathrm{CO}_{2}$ are still high when the strong convection related to the onset of the monsoon sets in at lower latitudes, and upper tropospheric levels of $\mathrm{CO}_{2}$ increase due to convective transport. In July, this plume disappears and a small decrease in the $\mathrm{CO}_{2}$ mixing ratios at latitudes north of $30^{\circ} \mathrm{N}$ and a larger decrease at southern latitudes are observed. This trend continues in August and September and the formation of a "negative" plume is seen with lowest mixing ratios around $20^{\circ} \mathrm{N}$. In September, this feature extends north to $40^{\circ} \mathrm{N}$. No latitudinal variation is seen for $\mathrm{CO}_{2}$ in spring and autumn (not shown).

In the monsoon region, the maximum mixing ratio of $\mathrm{CO}_{2}$ is observed in June, the minimum mixing ratio in September. In contrast, for all CARIBIC flights to Asia from 2006 to 2008, including flights between Germany and India and between Germany and the Philippines, the maximum value is observed in May. Since the onset of the monsoon rains has a strong influence on the timing of the growth period, the monsoon activity could influence the seasonal cycle of $\mathrm{CO}_{2}$ and the time when maximum mixing ratios occur. In addition, it may also influence the amplitude of the seasonal cycle in that region by enhanced vertical transport of low$\mathrm{CO}_{2}$ boundary layer air in late summer. In June, a mean $\mathrm{CO}_{2}$ mixing ratio of $388.57 \pm 0.39 \mathrm{ppm}$ is observed, in September it is $381.21 \pm 0.33 \mathrm{ppm}$. Compared with monthly mean values measured at MLO (Conway et al., 2009), a similar maximum value of $388.62 \mathrm{ppm}$ is measured at the station. But while at MLO the maximum is observed in May, in the monsoon region it is observed in June, with a delay of one month. The minimum value of $382.70 \mathrm{ppm}$ at MLO is observed in September, concomitant with the minimum in the CARIBIC data, but it is higher than the CARIBIC value. Correcting both datasets for an average linear increase of $0.14 \mathrm{ppm} \mathrm{month}^{-1}$, derived from the time series of monthly mean $\mathrm{CO}_{2}$ mixing ratios at MLO from 1969-2007, yields an amplitude of the seasonal cycle in 2008 of $6.48 \mathrm{ppm}$ at MLO and $7.79 \mathrm{ppm}$ for CARIBIC.

For all CARIBIC flights between Germany and India and between Germany and the Philippines a mean amplitude of only $\sim 6 \mathrm{ppm}$ was derived for latitudes $10-40^{\circ} \mathrm{N}$. This result is in agreement with a value of about $6 \mathrm{ppm}$ derived from flask measurements at $10-30^{\circ} \mathrm{N}$ by the JAL/CONTRAIL collaboration during flights between Japan and Australia (Matsueda et al., 2008). These flights took place east of the monsoon plume at longitudes $153-140^{\circ} \mathrm{E}$ in $1993-2007$. In this data set, the maximum $\mathrm{CO}_{2}$ mixing ratio is typically observed in early May with a shift to the end of May at latitudes $10-20^{\circ} \mathrm{N}$, and the minimum is observed in late September. The fact that the amplitude of the seasonal cycle decreases with altitude throughout the free troposphere (Gurk et al., 2008), explains the somewhat smaller amplitude derived from aircraft measurements in comparison with the value observed at MLO. However, despite the higher altitude of the aircraft, the amplitude observed in the monsoon region in 2008 is markedly larger than that observed at MLO, and it is also higher than the average amplitude observed at similar altitudes further east.

At ground level, the monsoon circulation is associated with southwesterly winds. These low-level winds transport 

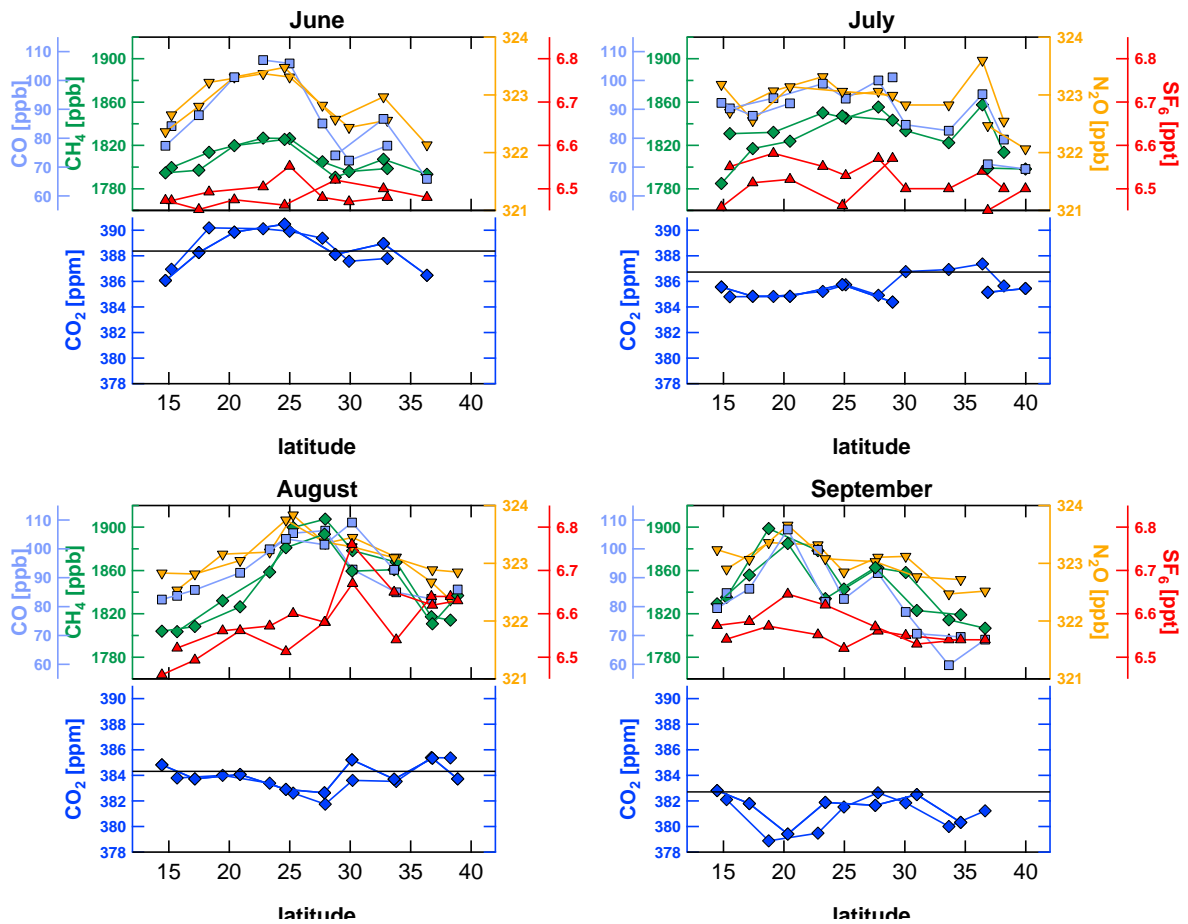

Fig. 5. Latitudinal distributions of $\mathrm{CH}_{4}, \mathrm{CO}_{2}, \mathrm{~N}_{2} \mathrm{O}$, and $\mathrm{SF}_{6}$ from air samples and on-line measured $\mathrm{CO}$ mixing ratios integrated over the sampling period for flights between Frankfurt and Chennai in June, July, August, and September 2008. For $\mathrm{CO}_{2}$ the mean mixing ratio observed at Mauna Loa Observatory $\left(19^{\circ} \mathrm{N}\right)$ is indicated by a solid line.

air from more southern latitudes towards South Asia. It the beginning of the rainy season, $\mathrm{CO}_{2}$ in the continental boundary is still relatively high, and the strong convection leads to the formation of a $\mathrm{CO}_{2}$ plume at higher altitudes. With the growing season's progress, additional $\mathrm{CO}_{2}$ is taken up by the vegetation. Because convection is still strong in late summer, low- $\mathrm{CO}_{2}$ air is effectively transported into the middle troposphere where then lower $\mathrm{CO}_{2}$ values are observed in the monsoon region than at corresponding latitudes further east, and the amplitude of the seasonal cycle increases.

\subsection{Latitudinal distributions of $\mathrm{O}_{3}$ and $\mathrm{H}_{2} \mathrm{O}$}

Ozone $\left(\mathrm{O}_{3}\right)$ and water vapor $\left(\mathrm{H}_{2} \mathrm{O}\right)$ are important atmospheric constituents discussed in many publications. The CARIBIC measurements also document their changes during the summer monsoon. Figure 6 shows $\mathrm{H}_{2} \mathrm{O}$ (top panels) and $\mathrm{O}_{3}$ (bottom panels) measurements integrated over the sampling period of each sample. In the latitudinal distribution of $\mathrm{H}_{2} \mathrm{O}$, a systematic offset depending on the direction of the flight route is noticeable for July, August and September. The reason is that samples collected at identical latitudes do vary in altitude, because of systematic altitude differences between outbound and inbound flights. In the beginning of a flight, the cruise altitude is lower due to the greater weight of the fully fueled aircraft. Therefore, flights from India back to Germany tend to show higher $\mathrm{H}_{2} \mathrm{O}$ mixing ratios for the southernmost samples taken closest to Chennai. Touch-down and take-off in Chennai took place within two hours during the night, and the southernmost sample was collected about one flight hour away from Chennai. This means that no major difference in convective activity due to different times of day should occur. Such an asymmetry is not observed for any of the other tracers with exception of one low-level sample in October showing an exceptionally high $\mathrm{CH}_{4}$ mixing ratio (cf. Fig. 4).

During all months from April through December, higher levels of $\mathrm{H}_{2} \mathrm{O}$ were observed towards southern latitudes with maximum values south of $20^{\circ} \mathrm{N}$. In June, July, and August, mixing ratios were always above $100 \mathrm{ppmv}$ south of $25^{\circ} \mathrm{N}$, with a steep decrease towards $30^{\circ} \mathrm{N}$. In September, this steplike decrease was seen a little further south, at $23-25^{\circ} \mathrm{N}$. In autumn and winter (not shown) the increase towards southern latitudes was less steep, and it was observed as an increase over a wider latitude range with values above $100 \mathrm{ppmv}$ only south of $20^{\circ} \mathrm{N}$.

$\mathrm{O}_{3}$ and $\mathrm{H}_{2} \mathrm{O}$ mixing ratios are generally seen to be anticorrelated throughout the observation period. During the summer months, a distinct increase of the $\mathrm{O}_{3}$ mixing ratio from $\sim 60 \mathrm{ppbv}$ to $\sim 100 \mathrm{ppbv}$ can be seen between 25 and $30^{\circ} \mathrm{N}$ in Fig. 6. Moreover, the latitudinal position of this increase is shifted slightly southward in September. High 

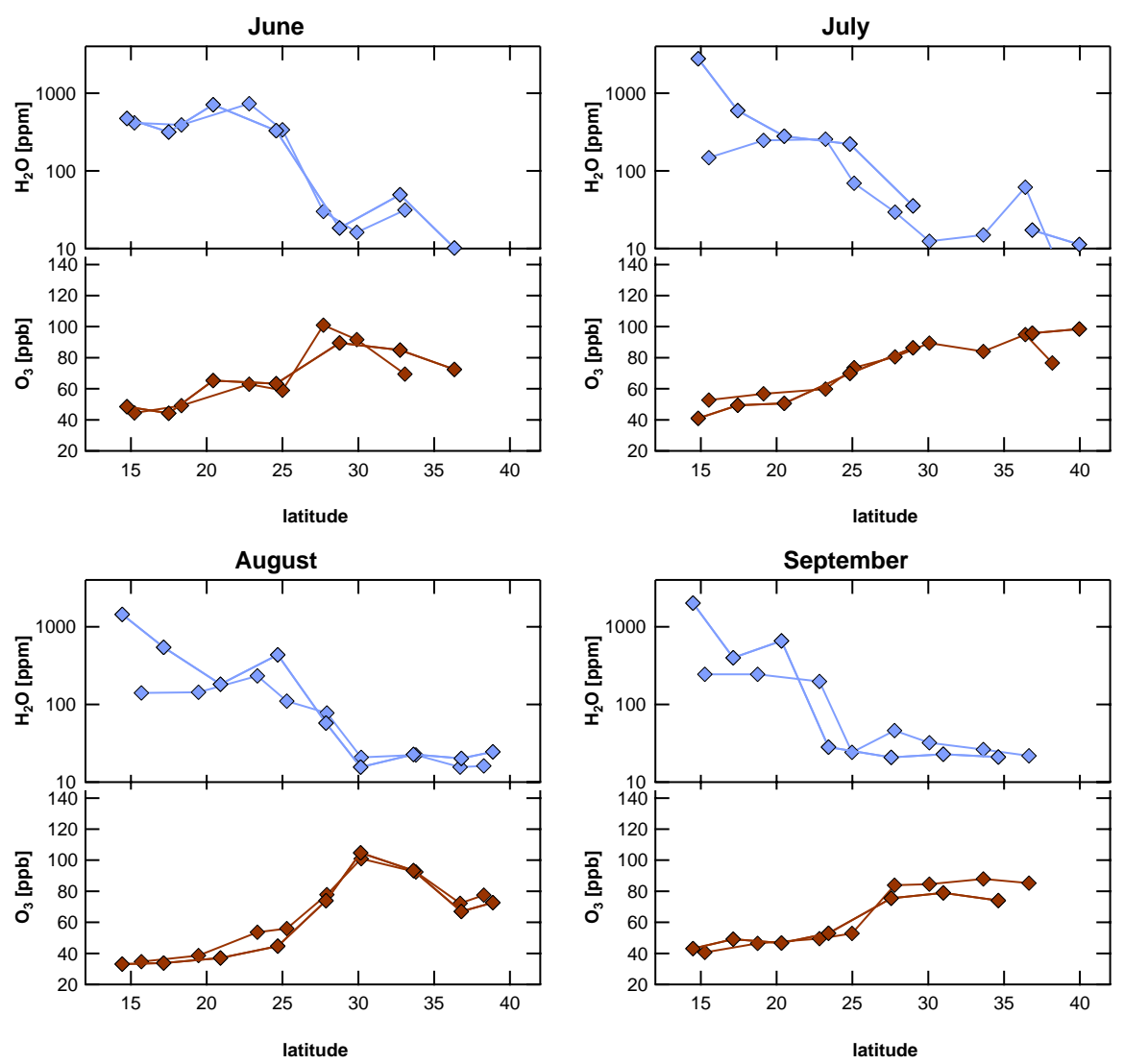

Fig. 6. Latitudinal distributions of $\mathrm{H}_{2} \mathrm{O}$ and $\mathrm{O}_{3}$ mixing ratios integrated over the sampling periods of whole air samples for flights between Frankfurt and Chennai in June, July, August and September 2008.

mixing ratios of $\mathrm{N}_{2} \mathrm{O}$ and $\mathrm{SF}_{6}$ and $\mathrm{PV}$ values $<0.6 \mathrm{PVU}$ at latitudes south of $30^{\circ} \mathrm{N}$ clearly indicate tropospheric air masses. The increase in $\mathrm{O}_{3}$ mixing ratios towards northern latitudes between $25^{\circ} \mathrm{N}$ and $30^{\circ} \mathrm{N}$ is accompanied by an increase in PV reaching maximum values of 1.3 PVU in summer. During the monsoon period, values of PV $>1.5 \mathrm{PVU}$ were only found north of $35^{\circ} \mathrm{N}$. The position of the steep increase in $\mathrm{O}_{3}$ at latitudes around $25^{\circ} \mathrm{N}$ corresponds to longitudes around $65^{\circ} \mathrm{E}$. The observation of elevated $\mathrm{O}_{3}$ mixing ratios in this region is in agreement with a summertime tropospheric $\mathrm{O}_{3}$ maximum over the Middle East predicted by model calculations ( $\mathrm{Li}$ et al., 2001). This maximum has been observed at pressures between $450 \mathrm{hPa}$ and $300 \mathrm{hPa}$ with the Tropospheric Emission Spectrometer, and is also in agreement with observations from the MOZAIC project (Liu et al., 2009; Worden et al., 2009). It was proposed that besides inmixing of stratospheric air, tropospheric $\mathrm{O}_{3}$ production from precursors carried by the easterly tropical jet may be a relevant process (Li et al., 2001; Liu et al., 2009). Non-methane hydrocarbon analyses of the CARIBIC samples (Baker et al., 2010a) indicate that there are different regimes in the monsoon region with variations in the $\mathrm{O}_{3}$ production potential which will be investigated in a separate study (?).
In the region of the monsoon anticyclone itself, satellite observations show an $\mathrm{O}_{3}$ minimum in the middle troposphere south of $25^{\circ} \mathrm{N}$ (Randel and Park, 2006; Liu et al., 2009; Liu et al., 2009), in agreement with what is observed during the CARIBIC flights. Data from the Global Ozone Monitoring Experiment (GOME) for 1997-2000 show considerable interannual variations in the strength and the extension of this $\mathrm{O}_{3}$ minimum (Liu et al., 2009). In the region where the steep increase in $\mathrm{O}_{3}$ is observed in the CARIBIC data $\left(25^{\circ} \mathrm{N}, 65^{\circ} \mathrm{E}\right)$, a similar increase from values below $70 \mathrm{ppbv}$ to more than $90 \mathrm{ppbv}$ was observed by the satellite instrument at $200 \mathrm{hPa}$ in 1997, 1998, and 2000. In 1999, it was observed further north in the same longitude band. It has been suggested that the formation of the $\mathrm{O}_{3}$ minimum is caused by tropical marine boundary layer air with a low $\mathrm{O}_{3}$ content that is carried by the low level southwesterlies towards the monsoon region where the $\mathrm{O}_{3}$ depleted air is then transported into the free troposphere. It was argued that the well defined $\mathrm{O}_{3}$ minimum is related to a blocking of northward flows by the Himalayas and the subtropical jet, both representing a barrier to transport (Liu et al., 2009). 
The steep cut-off observed in the $\mathrm{H}_{2} \mathrm{O}$ mixing ratio between $25^{\circ} \mathrm{N}$ and $30^{\circ} \mathrm{N}$ indeed indicates that convective uplifting of humid air is limited to this latitude band south of the Himalayas. Because the lifetime of gaseous $\mathrm{H}_{2} \mathrm{O}$ in the atmosphere is only of the order of days, it is effectively not transported horizontally, and the $\mathrm{H}_{2} \mathrm{O}$ plume is rather stationary, while tracers with longer lifetimes, such as the discussed greenhouse gases, may experience advection leading to a larger latitudinal extension of the plume in July, August and September. The atmospheric lifetime of $\mathrm{O}_{3}$ depends on photochemistry and is also influenced by convection (Lawrence et al., 2003), but usually is of the order of weeks and thus shorter than the lifetime of the greenhouse gases shown in Fig. 5. Randel and Park (2006) showed, using trajectory calculations, that the monsoon anticyclone can trap air masses for up to several weeks depending on altitude, with more effective confinement occurring at higher altitudes. Depending on a tracer's lifetime, advection in the free troposphere and accumulation in the monsoon plume may thus play an important role. The observation that for all discussed long-lived tracers atmospheric mixing ratios decrease towards $40^{\circ} \mathrm{N}$ is in agreement with the concept of air being confined in the anticyclone by a northern barrier hindering transport to latitudes further north.

\subsection{Plume shape and position}

In a simplifying approach, the spatial distributions of trace gas mixing ratios in the monsoon plume can be approximated by a Gaussian. Gaussian fits were applied to the observed latitudinal distributions, and from these mean latitudinal positions of the respective trace gas plumes and their maximum mixing ratios at these latitudes were determined. For CO, the continuous on-line measurements have been used. The inferred maximum mixing ratios are shown in Fig. 7a for May through September. For April and October the mean values over the latitude range $12-40^{\circ} \mathrm{N}$ are shown. For all four gases an increase throughout summer and a subsequent steep decrease at the end of the summer monsoon season is observed. $\mathrm{CH}_{4}$ and $\mathrm{SF}_{6}$ show a smooth and monotonous increase from April through August. $\mathrm{CO}$ and $\mathrm{N}_{2} \mathrm{O}$ behave similar, but show a local maximum in June.

Figure $7 \mathrm{~b}$ shows the latitudes at which the maximum mixing ratios are reached from May through September. Again, for all gases a similar systematic behavior is observed with the northernmost position being reached in August followed by a southward shift in September. The plume position as determined from the fits for these gases varies only within $2-7^{\circ}$ during one month. This scatter is mainly due to the values determined for $\mathrm{SF}_{6}$ for which the plume is slightly less well defined. For $\mathrm{SF}_{6}$ the mixing ratios are lowest, and the analytic uncertainty is, with a value of $0.9 \%$, larger than for the other compounds. For $\mathrm{SF}_{6}$ the uncertainty of the plume position varies from $1.1^{\circ}$ to $3.5^{\circ}$ (1- $\sigma$-uncertainty from fit). For $\mathrm{CH}_{4}$ and $\mathrm{N}_{2} \mathrm{O}$ the uncertainty of the plume latitude varies between $0.4^{\circ}$ and $1.6^{\circ}$, for $\mathrm{CO}$, for which the fit is performed using high resolution data, it is always below $0.1^{\circ}$. The relative error of the maximum mixing ratio is up to $14 \%$. For $\mathrm{CH}_{4}, \mathrm{~N}_{2} \mathrm{O}$, and $\mathrm{SF}_{6}$, the resulting functions are included in the latitudinal distributions shown in Fig. 8.

Figure $7 \mathrm{c}$ shows the concomitant changes in wind speed and $\mathrm{H}_{2} \mathrm{O}$ mixing ratios. The latitude at which maximum values of the zonal wind speed were observed indicates the latitudinal shift of the westerly jet, related to the migration of the monsoon anticyclone. From May until July, the maximum wind speed is observed at increasingly northern latitudes. In August, September and October a southward movement of the jet is observed. In addition, the latitude at which a zonal wind speed of $\sim 0 \mathrm{~m} / \mathrm{s}$ is observed, marking the position of the center of the anticyclonic circulation, is shown. It is located around $25^{\circ} \mathrm{N}$ in June, July and August, but further south in April, May and October. As an indicator of convective activity the latitude at which a $\mathrm{H}_{2} \mathrm{O}$ mixing ratio of $100 \mathrm{ppm}$ is observed is also shown. At more southern latitudes $\mathrm{H}_{2} \mathrm{O}$ mixing ratios exceed $100 \mathrm{ppm}$, at more northern latitudes they are lower, as can also be seen in Fig. 6. A clear northward shift of this latitude is observed from May to June. In parallel to the position of the anticyclonic center, indicated by zonal wind speeds of $0 \mathrm{~m} / \mathrm{s}$, the convective region does not progress north from June to August. Both observables show a southward shift from August to September, following the monsoon retreat. While the measurements of wind speed and $\mathrm{H}_{2} \mathrm{O}$ indicate little change in convective activity from June to August the maximum greenhouse gas mixing ratios are observed in August. This again shows that trapping of air masses in the circulation and accumulation of trace gases may play an important role, mostly relevant for longer-lived tracers.

The monsoon activity has strong variations on different timescales throughout one season which can cause short-time variations in the chemical composition of the atmosphere (Fujinami and Yasunari, 2004; Randel and Park, 2006). Maximum $\mathrm{CO}$ values can also be influenced by single pollution events. The CARIBIC flights took place once per month during three consecutive days yielding the first systematic in-situ observations of trace gases inside the monsoon plume. Although the observations do not represent monthly averages, they give a consistent picture of the highly systematic evolution of the plume reflecting the progression of the Indian summer monsoon.

\section{Trace gas enhancement in the monsoon plume}

\subsection{Enhancements of $\mathrm{CH}_{4}, \mathrm{SF}_{6}$, and $\mathrm{N}_{2} \mathrm{O}$}

In the northern hemisphere, ground station measurements show a pronounced seasonal cycle for $\mathrm{CH}_{4}$ with a smaller amplitude at high altitude locations and a strong northsouth gradient. Usually, a summer minimum is observed, 

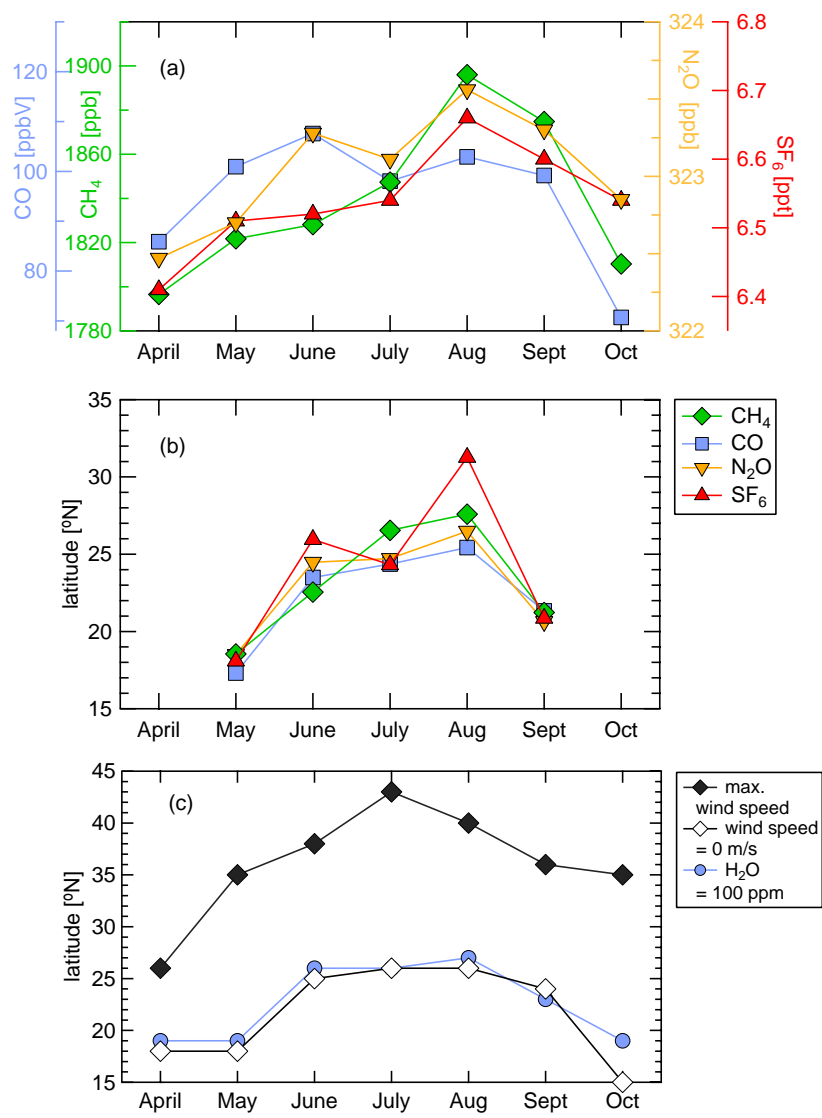

Fig. 7. (a) Maximum mixing ratios of $\mathrm{CH}_{4}, \mathrm{CO}, \mathrm{N}_{2} \mathrm{O}$, and $\mathrm{SF}_{6}$ observed in summer 2008 south of $40^{\circ} \mathrm{N}$. For April and October, when no monsoon plume is apparent, the monthly mean values are plotted. (b) Latitudinal position at which the maximum mixing ratios of $\mathrm{CH}_{4}, \mathrm{CO}, \mathrm{N}_{2} \mathrm{O}$, and $\mathrm{SF}_{6}$ were observed. (c) Latitudinal position of the maximum wind speed in the westerly jet and the latitude where the zonal wind speed is $0 \mathrm{~m} / \mathrm{s}$, both indicating the latitudinal position of the anticyclone. The latitude where $\mathrm{a}_{2} \mathrm{O}$ mixing ratio of $100 \mathrm{ppm}$ is observed indicates the northern extension of the strong convection.

predominantly due to reaction of $\mathrm{CH}_{4}$ with $\mathrm{OH}$ (Dlugokencky et al., 1994). In contrast, satellite observations and model simulations show a summer maximum in the free troposphere at $10-40^{\circ} \mathrm{N}$. Relative maxima of $\mathrm{CH}_{4}$ are seen over the Asian and the North American monsoon regions and are associated with enhanced vertical transport (Park et al., 2004). Figure 8 a again shows the latitudinal distributions of $\mathrm{CH}_{4}$ observed by CARIBIC. The measurements in April and October show an increase in mixing ratios with increasing latitude as observed by ground based measurements (Dlugokencky et al., 1994). But rather than a summer minimum, from June through August increasing mixing ratios are observed, in agreement with satellite observations.

To estimate the increase of the atmospheric methane load in the monsoon region, both, the seasonal and latitudinal variations of the atmospheric background need to be considered first. A background concentration is derived from the monthly mean values obtained from flask measurements at MLO in 2008 (Dlugokencky et al., 2009) and the latitudinal trend calculated from the CARIBIC October data. The resulting background estimates are shown as solid lines in Fig. 8a. Open symbols indicate samples with $\mathrm{CH}_{4}$ mixing below this background level. The latitudinal extension of the monsoon plume along the CARIBIC flight path indicated by the vertical dashed lines is defined by all samples with $\mathrm{CH}_{4}$ mixing ratios above the background level. Although there is not yet a distinct plume in April, five samples south of $25^{\circ} \mathrm{N}$ show enhanced mixing ratios relative to the background. From May through September, $\mathrm{CH}_{4}$ mixing ratios in the plume are significantly higher than the background values with a maximum enhancement of $\sim 123 \mathrm{ppb}$ observed at $28^{\circ} \mathrm{N}$ in August.

For $\mathrm{SF}_{6}$, shown in Fig. $8 \mathrm{~b}$, no plume structure is evident in the latitudinal distributions for April and October. In April, a mean value of $6.41 \pm 0.01 \mathrm{ppt}$ is observed, in October it is $6.54 \pm 0.01 \mathrm{ppt}$, resulting from an average monthly increase of $0.022 \mathrm{ppt}$. This is consistent with a value of $0.021 \mathrm{ppt}^{\text {month }}{ }^{-1}$ derived from all available CARIBIC data north of $10^{\circ} \mathrm{N}$ covering the time 1999-2001 and 2007-2009. Assuming the absence of a seasonal cycle and a linear trend for tropospheric $\mathrm{SF}_{6}$ allows an estimate to be made how large the background values would have been during the summer months if vertical transport would not have been enhanced in the monsoon region (solid horizontal lines in Fig. 8b). The CARIBIC observations in October do not show a latitudinal variation. In April, three samples collected north of $35^{\circ} \mathrm{N}$ show higher $\mathrm{SF}_{6}$ mixing ratios than the more southerly samples. These three samples also have lower $\mathrm{N}_{2} \mathrm{O}$ mixing ratios, but do not show deviations in $\mathrm{CH}_{4}$ or $\mathrm{CO}$. Although the corresponding PV integrals are low (0.51-0.61 PVU), the three samples are separated from the monsoon region by a high $\mathrm{PV}$ intrusion $(\mathrm{PV}=1.6-3.1 \mathrm{PVU})$ extending through the CARIBIC flight track at $\sim 35-28^{\circ} \mathrm{N}$ (van Velthoven, 2009). $\mathrm{O}_{3}$ mixing ratios in this filament exceeded $200 \mathrm{ppb}$ with maximum values of 460-490 ppb. This feature persisted for the three days during which the four successive CARIBIC flights took place, including the final two flights during which no sampling was performed. The samples collected in this high PV area were excluded in the present analysis, as only tropospheric samples are considered. Across the high PV area, the $\mathrm{SF}_{6}$ mixing ratio exhibits a gradient with values below $6.45 \mathrm{ppt}$ in the south and higher values in the north. Northwest of this feature, where the samples with high $\mathrm{SF}_{6}$ mixing ratios were collected, a small anticyclone was located over the Arabian peninsula embedded in the westerly jet, clearly separated from the monsoon anticyclone that was centered around $15^{\circ} \mathrm{N}$. For this flight, backward trajectories for all aircraft positions north of $20^{\circ} \mathrm{N}$ are influenced by the westerly jet and do not originate from the monsoon region. The $\mathrm{SF}_{6}$ enhancement is thus not related to convection in the monsoon 

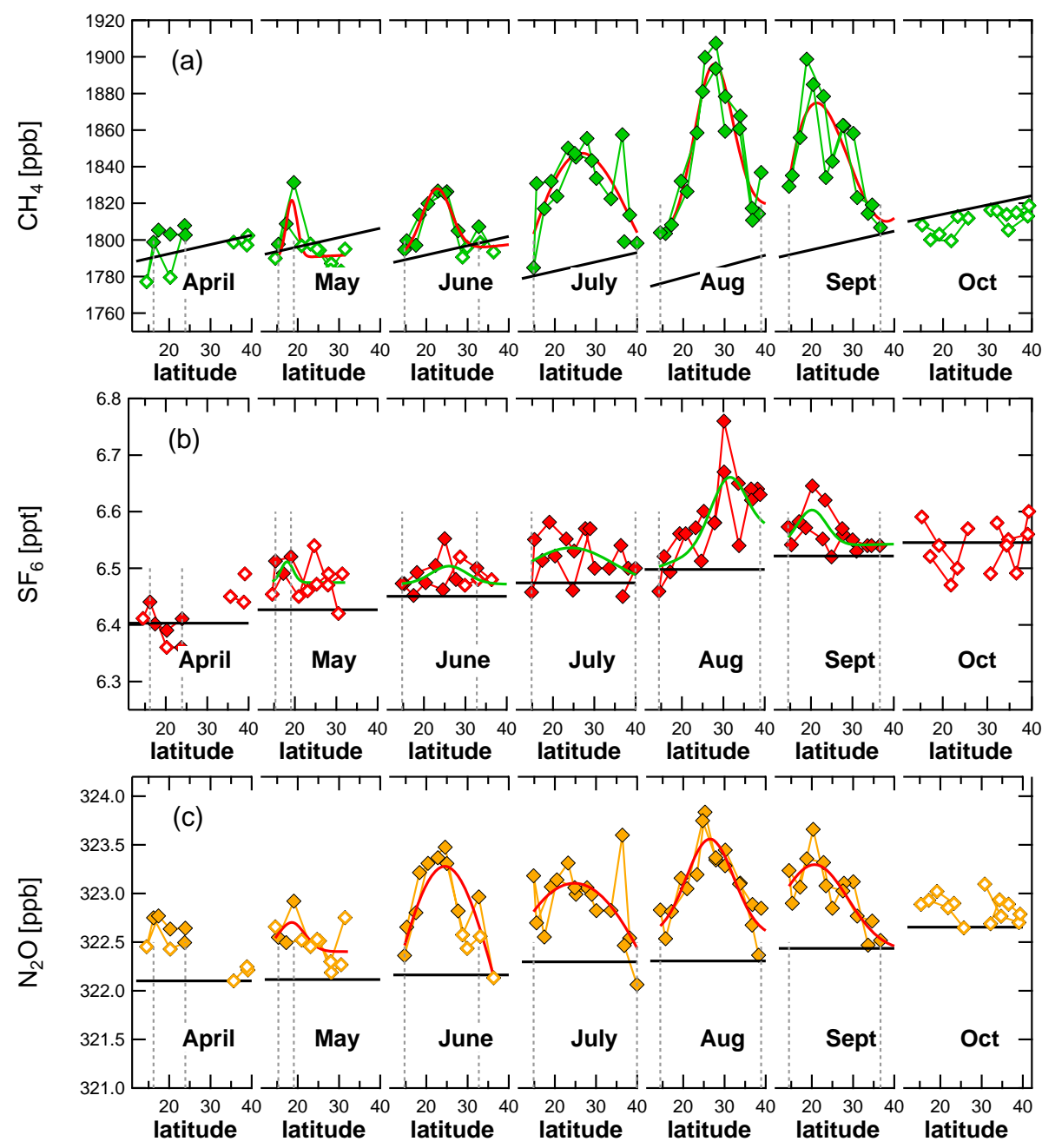

Fig. 8. Latitudinal distributions of $\mathrm{CH}_{4}(\mathbf{a}), \mathrm{SF}_{6}(\mathbf{b})$, and $\mathrm{N}_{2} \mathrm{O}$ (c) for April-October 2008. For May-September a Gaussian has been fit to the data. Solid lines indicate background levels determined from the CARIBIC measurements in April and October for SF 6 and from the Mauna Loa Observatory for $\mathrm{CH}_{4}$ and $\mathrm{N}_{2} \mathrm{O}$. All samples for which $\mathrm{CH}_{4}$ mixing ratios are above the reference background are indicated by closed symbols, open symbols denote samples with lower $\mathrm{CH}_{4}$ mixing ratios. The vertical dashed lines mark the integration limits used to calculate the increase in the monsoon plume.

region. Hence, the assumption of a constant $\mathrm{SF}_{6}$ background in the monsoon regions seems justified. Throughout summer not only the maximum mixing ratios increase in the plume, as shown in Fig. 7, but also the elevation relative to the background shows a clear seasonality. The maximum enhancement of $0.26 \mathrm{ppt}$ in an individual sample is observed in August at $30^{\circ} \mathrm{N}$.

$\mathrm{N}_{2} \mathrm{O}$ has a weak seasonal cycle in the $\mathrm{NH}$ troposphere, with a minimum in summer. (Morgan et al., 2004) pointed out that the observed summer minimum in the $\mathrm{N}_{2} \mathrm{O}$ seasonal cycle is caused by the downward flux of $\mathrm{N}_{2} \mathrm{O}$ depleted stratospheric air at high latitudes. Since rapid vertical transport occurs in the monsoon region, and the upper level anticyclonic circulation is associated with enhanced transport of tropospheric air into the stratosphere rather than vice versa (Chen,
1995; Traub and Lelieveld, 2003; Fu et al., 2006; Krishnamurti et al., 2008), influx of stratospheric air is unlikely to influence $\mathrm{N}_{2} \mathrm{O}$ mixing ratios in the monsoon plume, and thus a summer minimum is not expected in the monsoon region.

Figure $8 \mathrm{c}$ shows the latitudinal distributions of $\mathrm{N}_{2} \mathrm{O}$ measured during the CARIBIC flights. The solid lines indicate background mixing ratios derived from $\mathrm{N}_{2} \mathrm{O}$ data from the NOAA/ESRL halocarbons in situ program (Dutton et al., 2009). Given are monthly median values calculated from hourly collected air samples analyzed with a gas chromatograph at the Mauna Loa Observatory. In Fig. 8c, the seasonal cycle of $\mathrm{N}_{2} \mathrm{O}$ is not obvious in the MLO data, because it is masked by the continuous increase, and highest mixing ratios at MLO are observed in October. This is not the case for the CARIBIC data. In the monsoon region, higher mixing 
Table 1. Enhancement of $\mathrm{CH}_{4}, \mathrm{SF}_{6}, \mathrm{~N}_{2} \mathrm{O}$, and $\mathrm{CO}_{2}$ during the monsoon period, integrating along the CARIBIC flight track. No plume is observed in October.

\begin{tabular}{lccccc}
\hline & $\begin{array}{c}\Delta \mathrm{CH}_{4} \\
{[\mathrm{ppb}]} \\
\pm 10\end{array}$ & $\begin{array}{c}\Delta \mathrm{SF}_{6} \\
{[\mathrm{ppt}]} \\
\pm 0.02\end{array}$ & $\begin{array}{c}\Delta \mathrm{N}_{2} \mathrm{O} \\
{[\mathrm{ppb}]} \\
\pm 0.1\end{array}$ & $\begin{array}{c}\Delta \mathrm{CO} \\
{[\mathrm{ppb}]} \\
\pm 5\end{array}$ & $\begin{array}{c}\Delta \mathrm{CO}_{2} \\
{[\mathrm{ppm}]} \\
\pm 0.3\end{array}$ \\
\hline April & 12.03 & -0.01 & 0.55 & 2.81 & 0.34 \\
May & 16.73 & 0.08 & 0.50 & 2.56 & 0.37 \\
June & 18.52 & 0.04 & 0.90 & 7.70 & 0.95 \\
July & 45.13 & 0.05 & 0.63 & 19.29 & -1.10 \\
August & 65.76 & 0.09 & 0.81 & 29.36 & -0.52 \\
September & 51.92 & 0.04 & 0.58 & 18.68 & -1.65 \\
October & - & - & - & - & - \\
\hline Jun-Sep. av. & 45.33 & 0.06 & 0.73 & 18.75 & -0.58 \\
\hline
\end{tabular}

ratios are observed in summer than in October, with mixing ratios in the plume clearly exceeding the background levels at MLO.

\subsection{Quantification of tracer enhancements}

Considering all samples with $\mathrm{CH}_{4}$ mixing ratios above the Mauna Loa reference line for the respective month defines the spatial extension of the monsoon plume along the CARIBIC flight track. In Fig. 8, the latitude range that is covered by the plume samples is indicated by the vertical dashed lines. The area between the data points and the background then yields the excess amount of $\mathrm{CH}_{4}$ in the atmosphere that is contained in the monsoon plume. From the integration of the observed trace gas mixing ratios over the latitude range defined by the samples with elevated $\mathrm{CH}_{4}$, the mean mixing ratio increase in the plume can be calculated for each gas. Note that the Gaussian fits in Fig. 8 are included for illustration only, and all integrations have been performed numerically using the measured mixing ratios and sampling positions. Table 1 lists the average increase of $\mathrm{CH}_{4}, \mathrm{SF}_{6}$, $\mathrm{N}_{2} \mathrm{O}, \mathrm{CO}_{2}$ and $\mathrm{CO}$ for April through September. The numbers for $\mathrm{CO}$ have been calculated from the continuous measurements using mean values observed at MLO as reference values (Novelli and Masarie, 2009).

In April, no significant increase in the mixing ratios at flight altitude is observed for all gases except for $\mathrm{N}_{2} \mathrm{O}$. The observed $\mathrm{SF}_{6}$ increase is close to $0 \mathrm{ppt}$, indicating little convective activity, and the $\mathrm{CH}_{4}$ increase is only $12.03 \mathrm{ppb}$, close to the standard deviation of the data which is $10.31 \mathrm{ppb}$. For $\mathrm{CH}_{4}$ and $\mathrm{CO}$, initially strongly increasing enhancements are observed with maxima in August and lower values in September. This pattern is similar for $\mathrm{SF}_{6}$, except that in May the increase is almost as strong as in August. This is plausible if air masses would have mainly originated from industrialized regions with strong local $\mathrm{SF}_{6}$ sources.
For $\mathrm{N}_{2} \mathrm{O}$, a higher value is observed in August compared to July and September, but the maximum enhancement is observed in June. In April, the increase is similar to that in September. Figure 8 shows that in April the background level from MLO corresponds to the mixing ratios measured in the samples that were collected north of the high PV intrusion, while the samples collected further south have higher values. Throughout the summer, the CARIBIC observations approach the MLO background at the edges of the plume, and in October this applies to the whole latitude range. Various studies on $\mathrm{N}_{2} \mathrm{O}$ emissions from rice paddies show strong variations depending on fertilization and water management (e.g. Cai et al., 1997; Akiyama et al., 2005 and references therein). Especially flooding practices such as intermittent drainages of rice paddies may influence $\mathrm{N}_{2} \mathrm{O}$ emissions. It was found that emissions of $\mathrm{CH}_{4}$ and $\mathrm{N}_{2} \mathrm{O}$ do not occur simultaneously. $\mathrm{CH}_{4}$ is mainly emitted during the growing season, when rice paddies are flooded, while the monsoon convection is active. In contrast, $\mathrm{N}_{2} \mathrm{O}$ emissions occur mainly during the fallow period (Cai et al., 1997; Nishimura et al., 2004) after the growing season, and over a short time interval at the beginning of the irrigation period, earlier than the $\mathrm{CH}_{4}$ emissions. The different seasonality of emissions could thus explain the relatively large increase observed in $\mathrm{N}_{2} \mathrm{O}$ mixing ratios in June.

$\mathrm{CO}_{2}$ shows an insignificant increase in April and May and a somewhat larger enhancement in June, indicating that at the beginning of the monsoon period, when strong convection sets in, ground level mixing ratios of $\mathrm{CO}_{2}$ are still relatively high. This indicates that although the monsoon onset with strong rainfall happens in late May/early June there is a delay in the uptake of $\mathrm{CO}_{2}$ by the vegetation that is reflected in a delay in the upper troposphere seasonal cycle. From July through August, a decrease in the $\mathrm{CO}_{2}$ mixing ratio is observed in the plume. The minimum in the seasonal cycle occurs in September when also the decrease relative to MLO is largest.

\subsection{Structure of the plume}

During its seasonal evolution the plume is changing in size, and it is moving northwest during the growing phase and southeast during the monsoon retreat. With summer progressing, the CARIBIC transect therefore probes different parts of the upper level anticyclone. Comparing outbound and return flights which, as mentioned above, show a systematic difference in flight altitude, higher water vapor mixing ratios were found for the southernmost samples upon leaving Chennai. These samples are collected about $1.5-3 \mathrm{~km}$ lower than the corresponding samples from the outbound flights. In the greenhouse gas distributions no influence of the altitude can be seen, and this is also the case for $\mathrm{CO}$ and $\mathrm{O}_{3}$. This indicates that in the altitude range $8-12 \mathrm{~km}$ there is little vertical structure in the plume for the longer-lived gases. 
The CARIBIC aircraft crosses the plume at $55-80^{\circ} \mathrm{E}$. The maximum greenhouse gas mixing ratios are observed around $28^{\circ} \mathrm{N} 65^{\circ} \mathrm{E}$, while the center of the anticyclone, where maximum mixing ratios of $\mathrm{CH}_{4}$ occur, is located further east, around $28^{\circ} \mathrm{N} 80^{\circ} \mathrm{E}$. There, according to satellite observations $\mathrm{CH}_{4}$ mixing ratios are higher but currently nothing is known about the concentrations of $\mathrm{SF}_{6}$ and $\mathrm{N}_{2} \mathrm{O}$.

Backward trajectories based on ECMWF data show systematic patterns depending on the sampling location. Figure 9 (top panel) shows two examples of 10-day backward trajectories from a flight from Frankfurt to Chennai on 13 August 2008 , one collected at $38.3^{\circ} \mathrm{N} 42.2^{\circ} \mathrm{E}$ at $216 \mathrm{hPa}$, the second collected at $25.3^{\circ} \mathrm{N} 66.6^{\circ} \mathrm{E}$ at $196 \mathrm{hPa}$. Blue colors indicate high altitudes, red and yellow colors indicate low altitudes. The trajectories are calculated over the sampling period for every $6 \mathrm{~s}$ of flight. For the northern sample the trajectory bundle is very compact with little dispersion. The air is moving rapidly within the outer parts of the anticyclone at altitudes above $250 \mathrm{hPa}$, without ground contact over the period of ten days. Similar trajectories are found for all samples collected in the monsoon plume north of $30^{\circ} \mathrm{N}$. This air has already been part of the anticyclonic circulation for more than one week. A detailed analysis of chemical ages of air masses in the plume performed using non-methane hydrocarbon measurements will be published separately (?).

In contrast, trajectories for samples from the plume center and from the southern part of the circulation are much more diverse, usually with ground contact one to four days prior to sampling, so that the air had only recently been uplifted. The trajectory bundle is less compact and usually spreads over a larger area at altitudes below $300 \mathrm{hPa}$. The example in Fig. 9 illustrates the transport of air over the Arabian Sea towards the Indian subcontinent at altitudes below $850 \mathrm{hPa}$. Between $80^{\circ} \mathrm{E}$ and $95^{\circ} \mathrm{E}$ the flow turns around, and the air masses ascend, ultimately entering the upper tropospheric circulation. Also the trajectory patterns for samples collected south of $30^{\circ} \mathrm{N}$ are less homogeneous than for the northern samples. For all samples collected south of $20^{\circ} \mathrm{N}$ the turning point of the air flow is located over the Indian landmass or over the Bay of Bengal, close to the Indian east coast. For these samples, emissions from the densely populated subcontinent will mainly influence free tropospheric trace gas mixing ratios. For samples collected between $20^{\circ} \mathrm{N}$ and $30^{\circ} \mathrm{N}$ the position of the turning point varies. Often it lies over the Bay of Bengal, or the turn may occur over the western part of Mainland Southeast Asia. Here, greenhouse emissions are generally lower than from the densely populated northern Indian plains. Emission values quoted for India have therefore been used as a reference. Of the 62 plume samples only five trajectories indicate an influence of emissions east of $100^{\circ} \mathrm{E}$. These regions are thus unlikely to influence the CARIBIC measurements in the western part of the anticyclone.

Figure 9 (bottom panel) shows a calculation of five day forward trajectories originating along the flight path of the CARIBIC aircraft for the flight section between 12:00 h UTC and 18:00 h UTC, for every $3 \mathrm{~min}$ of flight. The forward calculation also shows the air flow in the westerly jet north of the monsoon anticyclone that is crossed between $\sim 42^{\circ} \mathrm{N}$ and $\sim 32^{\circ} \mathrm{N}$. Air masses encountered south of $\sim 32^{\circ} \mathrm{N}$ are part of the anticyclonic circulation. Air masses around $\sim 32^{\circ} \mathrm{N}$ that are transported with the monsoon circulation may eventually enter the jet stream to be transported east across the Pacific.

\section{Estimates of emissions from the monsoon region}

\subsection{Scheme for emission estimates}

In the following a simple model will be applied to derive emission estimates from the measured trace gas enhancements in the monsoon plume, extending methods commonly used for small-scale plumes. The underlying concept is a small flux of highly polluted boundary layer air that is rapidly uplifted by convection and mixed into upper tropospheric background air.

The simultaneous measurements of several trace gases in the monsoon plume can be used to derive emission estimates using one gas as a reference for which emissions need to be known. From the suite of tracers measured on the CARIBIC air samples, $\mathrm{SF}_{6}$ has been chosen as reference gas because it is a chemically inert, purely anthropogenic tracer with sources in the South Asian monsoon region that can be assumed to have no seasonal variation. Supposed that $\mathrm{SF}_{6}$ emissions remain constant during the monsoon period, it follows that the additional $\mathrm{SF}_{6}$ in the plume is entirely due to more effective vertical transport during the monsoon period. Emissions of $\mathrm{CH}_{4}, \mathrm{~N}_{2} \mathrm{O}$ and $\mathrm{CO}$ can then be calculated for the monsoon months relative to the emissions of $\mathrm{SF}_{6}$, and if these are known, absolute fluxes can be derived.

Another assumption that needs to be made is a similar spatial distribution of emission sources. While $\mathrm{SF}_{6}$ is an industrial tracer, the most important $\mathrm{CH}_{4}$ sources in the monsoon region are rice paddies, wetlands, landfills, and ruminants. $\mathrm{N}_{2} \mathrm{O}$ is emitted mainly from soils (Mosier et al., 1998) and estimations of the contribution of rice farming have large uncertainties (Akiyama et al., 2005). These different sources will most likely not be strictly co-located. However, for all gases, strong emissions originate in the densely populated Ganges-Indus plains in northern India. Different types of emission sources are distributed over this region that can be seen as a mosaic of point sources, and it can be assumed that transport into the free troposphere occurs under similar conditions for all gases. Furthermore, it is required that the compared tracers behave similarly during atmospheric transport. Due to their long lifetimes, the greenhouse gases $\mathrm{CH}_{4}, \mathrm{SF}_{6}$, $\mathrm{N}_{2} \mathrm{O}$, and $\mathrm{CO}_{2}$ can be considered as chemically inert tracers during the four months duration of the monsoon period. For $\mathrm{CO}$, with a lifetime of the order of weeks to months, this may still be an acceptable approximation. 

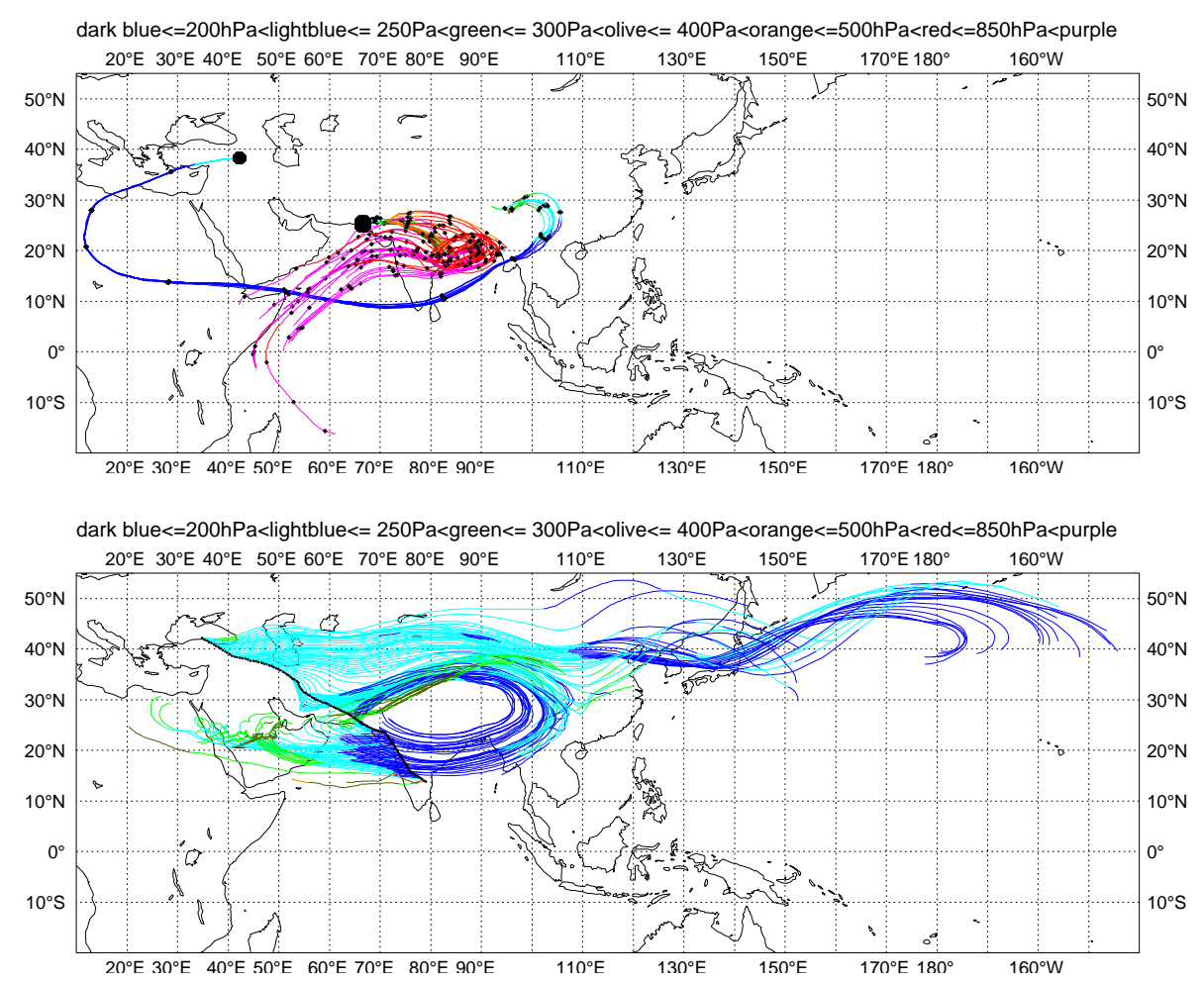

Fig. 9. Top: Ten day backward trajectories for two samples collected at $216 \mathrm{hPa}$ and at $196 \mathrm{hPa}$ on 13 August 2008 during a flight from Frankfurt to Chennai. Along the trajectories, small markers indicate time steps of $24 \mathrm{~h}$, the large symbols denote the sampling positions. Bottom: Five day forward trajectories calculated every 3 min along the flight track on August 13th 2008.

Frequently, the source-tracer-ratio (STR) method is used to derive emission estimates for a tracer that is measured under the same conditions as a second tracer with a known emission rate. Emissions are estimated from the correlations of tracer mixing ratios, and for example $\mathrm{CH}_{4}$ emissions $E_{\mathrm{CH}_{4}}$ can be calculated from emissions $E_{\mathrm{SF}_{6}}$ of $\mathrm{SF}_{6}$ as

$E_{\mathrm{CH}_{4}}=E_{\mathrm{SF}_{6}} \cdot \mathrm{ER}_{\mathrm{CH}_{4} / \mathrm{SF}_{6}}$,

$\mathrm{ER}_{\mathrm{CH}_{4} / \mathrm{SF}_{6}}$ being the emission ratio of $\mathrm{CH}_{4}$ to $\mathrm{SF}_{6}$ calculated from the correlation of both tracers in the plume (Andreae and Merlet, 2001). The successful usage of $\mathrm{SF}_{6}$ as a reference tracer using this STR method in tracer release experiments has for example been reported in (Lamb et al., 1995; Möllmann-Coers et al., 2002). Equation 1 does not demand a priori assumptions about the tracer background concentrations in the free troposphere.

Figure 10 shows as an example the correlations of $\mathrm{CH}_{4}$, $\mathrm{N}_{2} \mathrm{O}$, and $\mathrm{CO}$ for September. The correlation coefficients $r$ are $0.49\left(\mathrm{CH}_{4}\right), 0.70\left(\mathrm{~N}_{2} \mathrm{O}\right)$, and $0.58(\mathrm{CO})$. Also shown are the respective regression lines and the reference values that were used as background values in Sect. 5 (see Fig. 8). For all tracers, including $\mathrm{CO}_{2}$ which is not shown here, the background values fall within the confidence band of the regression line. The correlation slopes are determined using weighted orthogonal regression, and errors are calculated considering the analytical uncertainty of each data point. Because the range of mixing ratios in the plume is rather small, and the reference gas $\mathrm{SF}_{6}$ has the largest measurement uncertainty of the discussed tracers, this results in large uncertainties in the estimated emission ratios. The tracer correlations are only statistically significant (on the $95 \%$ level, according to a t-test) in July and September, and no significant correlation was found for $\mathrm{CO}_{2}$, which limits the applicability of the STR method for the current dataset.

A second way to estimate emissions is to compare the enhancement of the tracers relative to the atmospheric background (Andreae and Merlet, 2001). This will be referred to as the integration method. In this case, assumptions need to be made about tracer background mixing ratios. The observed mixing ratio increase $\Delta c$ in the plume relative to the background value $c$ indicates the existence of an additional net flux $\varphi \sim \Delta c$. Surface emissions $E$ represent a flux into the boundary layer of which a fraction is transported rapidly up to the plume altitude. This fraction is determined by the local strength of the convective activity. Assuming rapid convective transport without dilution and sinks the flux into the upper troposphere can be assumed to be proportional to the emissions $E$, and the resulting increase of mixing ratios $\Delta c$ is also proportional to the emissions $E$. Then the same ratio 


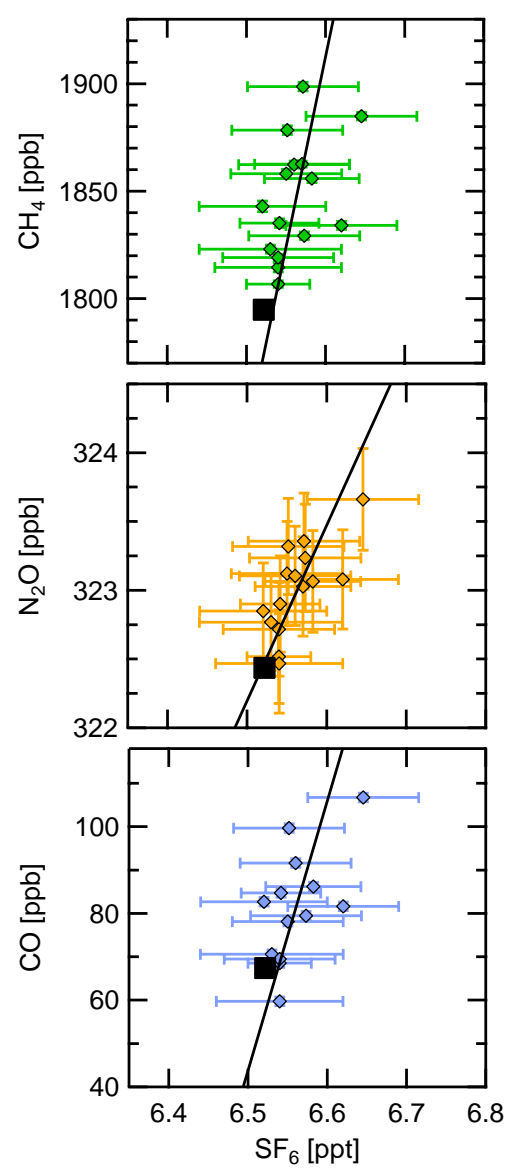

Fig. 10. Correlation of $\mathrm{CH}_{4}, \mathrm{~N}_{2} \mathrm{O}$, and $\mathrm{CO}$ with $\mathrm{SF}_{6}$ in the monsoon plume in September. The black lines result from a weighted orthogonal distance regression, the black squares indicate the background mixing ratios $\mathrm{SF}_{6}$ interpolated from CARIBIC data, $\mathrm{CH}_{4}$ and $\mathrm{CO}$ mean value, $\mathrm{N}_{2} \mathrm{O}$ median observed at MLO in September 2008).

applies for the trace gas enhancements in the monsoon plume and for the corresponding surface emissions

$\frac{\Delta c_{\mathrm{CH}_{4}}}{\Delta c_{\mathrm{SF}_{6}}}=\frac{\varphi_{\mathrm{CH}_{4}}}{\varphi_{\mathrm{SF}_{6}}}=\frac{E_{\mathrm{CH}_{4}}}{E_{\mathrm{SF}_{6}}}$,

and the summer time emission of $\mathrm{CH}_{4}$ can be estimated as

$E_{\mathrm{CH}_{4}}=E_{\mathrm{SF}_{6}} \cdot \frac{\Delta c_{\mathrm{CH}_{4}}}{\Delta c_{\mathrm{SF}_{6}}}$.

To determine the value of $\Delta c$ with the integration method, for each gas a numerical integration of trace gas mixing ratios over latitude was performed for the samples that were collected in the plume. This procedure yields an average mixing ratio increase in the plume (cf. Table 1) from which monthly emissions can be estimated using Eq. (3). Thereby it is again assumed that emissions of $\mathrm{SF}_{6}$ and the other gases occur from similarly distributed sources, and that tropospheric sinks are the same for all gases. $\mathrm{SF}_{6}$ has no tropospheric sink, and due to the rapid vertical transport and the long lifetime this assumption is certainly justified for $\mathrm{CH}_{4}, \mathrm{CO}_{2}$, and $\mathrm{N}_{2} \mathrm{O}$ and to first approximation also for $\mathrm{CO}$.

In the following, the EDGAR database is used as a reference for greenhouse gas emission rates (V4.0, (Olivier et al., 2005), data obtained from http://edgar.jrc.ec.europa.eu/ index.php). Trajectories indicate that the CARIBIC measurements are strongly influenced by emissions from the Indian subcontinent (see also Sect. 5.3), therefore the most recent emission rates quoted for India will be used for comparison. But it has to be reiterated that the footprint is not completely the same for all tracers due to the distribution of sources. For India, $\mathrm{SF}_{6}$ emissions $E_{\mathrm{SF}_{6}}$ of $0.192 \mathrm{Gg}$ are reported for 2005 , corresponding to a mean monthly flux of $0.016 \mathrm{Gg}$ or $0.11 \times 10^{6} \mathrm{~mol} / \mathrm{month}$. Based on this value, both, equation 3 and equation 1 have been used to derive emission estimates for each month during the monsoon period. Estimating emissions month by month it is assumed that the measured trace gas enhancements are entirely due to emissions during one month without a continued piling-up in the plume.

For the months with statistically significant tracer-tracer correlations the results from both methods agree within $\sim 30 \%$, and in the following only the results from the integration method listed in Table 2 will be discussed. The errors of the emission rates were estimated from the mixing ratio difference observed in samples collected at the same latitude within one day during consecutive flights and from the standard deviation observed in October and April.

\subsection{Emissions of $\mathrm{CH}_{4}, \mathrm{~N}_{2} \mathrm{O}$ and $\mathrm{CO}$}

The above integration-based estimates of the $\mathrm{CH}_{4}$ emissions from the monsoon region show an increase during the summer from $0.9 \mathrm{Tg}$ in June to $2.3 \mathrm{Tg}$ in September with an average $\mathrm{CH}_{4}$ emission rate of $1.5 \mathrm{Tg} /$ month. This seasonal trend can be explained by a strong increase in emissions from seasonally varying sources such as rice paddies, wetlands and landfills during the rainy season (Bogner and Spokas, 1993; Chen and Prinn, 2006; Khalil and Butenhoff, 2008). Although absolute $\mathrm{CH}_{4}$ fluxes are not very well known, the seasonality derived from the CARIBIC observations is consistent with the expected strong influence of rice agriculture and seasonally important sources such as wetlands. In India these sources are estimated to account for $\sim 1 / 3$ of the total emissions which were reported $28.1 \mathrm{Tg}$ in 2005 in the EDGAR database. This corresponds to a monthly average of $2.34 \mathrm{Tg} / \mathrm{month}$ when no seasonality of emissions is considered, higher than the CARIBIC estimate of $1.5 \mathrm{Tg} / \mathrm{month}$. Because our estimate is based on $\mathrm{SF}_{6}$ emissions from the data base, this may point to an overestimation of $\mathrm{CH}_{4}$ emissions or an underestimation of $\mathrm{SF}_{6}$ emissions in South Asia, or both.

Another reason for this relatively low value may be the position of the flight track. In the center of the anticyclone, 
Table 2. Estimates of total net fluxes for $\mathrm{CH}_{4}, \mathrm{~N}_{2} \mathrm{O}, \mathrm{CO}$, and $\mathrm{CO}_{2}$ based on India's assumed $\mathrm{SF}_{6}$ emissions in 2005. Error estimates are $\sim 50 \%$ for all tracers. Emission data from the EDGAR inventory are for India in $2005\left(\mathrm{v} 4.0, \mathrm{CH}_{4}, \mathrm{~N}_{2} \mathrm{O}\right)$ and 2000 (v3.2, CO).

\begin{tabular}{lcccr}
\hline & $\begin{array}{c}\mathrm{CH}_{4} \\
{[\mathrm{Tg} / \text { month }]}\end{array}$ & $\begin{array}{c}\mathrm{N}_{2} \mathrm{O} \\
{[\mathrm{Gg} / \text { month }]}\end{array}$ & $\begin{array}{c}\mathrm{CO} \\
{[\mathrm{Tg} / \text { month }]}\end{array}$ & $\begin{array}{c}\mathrm{CO}_{2} \\
{[\mathrm{Tg} / \mathrm{month}]}\end{array}$ \\
\hline June & 0.9 & 114.5 & 0.7 & 121.2 \\
July & 1.6 & 60.6 & 1.3 & -106.5 \\
August & 1.3 & 43.4 & 1.1 & -28.1 \\
September & 2.3 & 69.6 & 1.6 & -198.9 \\
\hline Jun-Sep av. & 1.5 & 72.0 & 1.2 & -53.1 \\
\hline EDGAR database & 2.3 & 52.7 & 5.3 & \multicolumn{1}{|}{-} \\
\hline
\end{tabular}

where, according to satellite observations, $\mathrm{CH}_{4}$ mixing ratios are highest, also the fraction $\frac{\Delta c_{\mathrm{CH}_{4}}}{\Delta c_{\mathrm{SF}_{6}}}$ may reach its maximum, because the relative increase of $\mathrm{CH}_{4}$ and $\mathrm{SF}_{6}$ in the plume may be different. In conclusion the CARIBIC data indicate strong seasonal changes of $\mathrm{CH}_{4}$ emissions during the monsoon season. On average, the emission estimates based on these data are lower than the average monthly values reported in the EDGAR database which does not consider the seasonality of emissions.

Emissions of $\mathrm{N}_{2} \mathrm{O}$ are particularly difficult to assess because individual sources such as soil emissions or indirect emissions from rice farming may undergo very different seasonal variations. $\mathrm{N}_{2} \mathrm{O}$ emissions derived from the CARIBIC data show a decrease from $114.5 \mathrm{Gg}$ to $43.4 \mathrm{Gg}$ throughout the summer. This is consistent with results from observations in rice paddies showing an anti-correlation between $\mathrm{CH}_{4}$ and $\mathrm{N}_{2} \mathrm{O}$ emissions (Nishimura et al., 2004). In the EDGAR inventory, emissions of $632 \mathrm{Gg}$ were quoted for 2005 , corresponding to average monthly emissions of $52.7 \mathrm{Gg} /$ month. This is somewhat smaller than the average value of $72.0 \mathrm{Gg} /$ month derived from the observations. However, the monthly mean value from the data archive again does not consider the seasonality of emissions from different sources.

The third column of Table 2 lists monthly emissions of $\mathrm{CO}$ during the monsoon period estimated with the integration method. $\mathrm{CO}$ has a much shorter lifetime than $\mathrm{CH}_{4}$, therefore, the assumption of insignificant losses is not valid. While losses during the convective vertical transport are small because it happens rapidly, $\mathrm{CO}$ continues to react with $\mathrm{OH}$ at higher altitudes while air masses are transported within the anticyclone. With a rate coefficient of $k=1.5 \times 10^{-13} \cdot(1+$ $0.6 p) \mathrm{cm}^{3} \mathrm{~s}^{-1}$, at a pressure of $p=200 \mathrm{hPa}$ and an $\mathrm{OH}$ concentration $[\mathrm{OH}]=1 \times 10^{6} \mathrm{~cm}^{-3}$ for $12 \mathrm{~h}$ per day (Spivakovsky et al., 2000; DeMore et al., 1997) about $80 \%$ of the initial $\mathrm{CO}$ will be left after one month. The above calculation is therefore expected to underestimate the monthly emissions accordingly. In addition, satellite observations (Kar et al., 2004; Park et al., 2009) indicate that the maximum CO mixing ratios in the plume center exceed the maximum value of $\sim 110 \mathrm{ppb}$ measured by CARIBIC so that the position of the flight route west of the center may also result in an underestimation of emissions as discussed in the previous section for $\mathrm{CH}_{4}$.

The estimated emissions of $\mathrm{CO}$ are lower at the beginning of the monsoon season. A plausible reason for this is a decrease in emissions from wildfires and agricultural biomass burning during the rainy season. Biomass burning emissions based on GFED v2 data (Randerson et al., 2007) show minimum biomass burning activity during summer. Consequently, $\mathrm{CO}$ emissions will mainly originate from industrial sources, transportation and from domestic biofuel use, and their location will be similar to the distribution of $\mathrm{SF}_{6}$ sources. On average, a value of $1.2 \mathrm{Tg} /$ month is obtained during the monsoon period. The most recent data available is for 2000 (EDGAR 3.2 Fast Track 2000). Total emissions of $63.8 \mathrm{Tg}$ are quoted for India, including a contribution from biomass burning averaged for 1997-2001. This corresponds to a mean value of $5.3 \mathrm{Tg} /$ month, considerably more than what is derived here from the CARIBIC flights. A seasonality of emissions is not resolved in the EDGAR data archive, and the monthly mean value derived from the yearly emissions from the data archive is most likely an overestimate during summer, because it does not consider an emission decrease in summer.

\subsection{The $\mathrm{CO}_{2}$ flux}

The last column of Table 2 lists $E_{\mathrm{CO}_{2}}$ according to Eq. (3). $\mathrm{CO}_{2}$ has strong emissions from fossil fuel, biofuel, and wood burning, but there is also a very large downward flux due to uptake of $\mathrm{CO}_{2}$ by the vegetation during the growing season. Thus, this number $E_{\mathrm{CO}_{2}}$ does not quantify emissions into the free troposphere but rather a net flux of $\mathrm{CO}_{2}$. This flux is positive in June but changes sign in July reflecting the increasing $\mathrm{CO}_{2}$ uptake by the biosphere. This downward flux peaks in September when the lowest mixing ratios are observed at flight altitude. In August, the $\mathrm{CO}_{2}$ uptake seems to be lower, parallel to a lower $\mathrm{CH}_{4}$ flux derived for this month, although plant growth and thus photosynthesis are 
not expected to weaken then. A possible explanation may be the variability of the monsoon activity. (Randel and Park, 2006) showed that variations in the convection strength, socalled active and break phases of the monsoon, are also reflected in upper tropospheric trace gas concentrations. In August, the upward vertical wind speed measured by the aircraft systems was lower around $20^{\circ} \mathrm{N}$, while the highest values were encountered in September. Therefore, the lower flux in August could reflect a decrease in convective activity masking increased emissions and uptake. The CARIBIC flights took place within three consecutive days during each month. Despite the highly systematic pattern, the representativeness of the data cannot be determined.

\section{Summary and conclusions}

Trace gas measurements from aboard the CARIBIC passenger aircraft during flights between Germany and India in 2008 show a clear monsoon signature in the free troposphere south of $40^{\circ} \mathrm{N}$ at altitudes between 8 and $12.5 \mathrm{~km}$. The most prominent feature is an enhancement in $\mathrm{CH}_{4}$ mixing ratios, accompanied by elevated levels of $\mathrm{SF}_{6}, \mathrm{~N}_{2} \mathrm{O}$, and $\mathrm{CO}$ throughout the summer monsoon season. These tracers appear to be closely related, showing increasing mixing ratios from May through August followed by a decrease in September. Latitudinal distributions of mixing ratios show a similar plume structure for all four gases. In October, after the monsoon season, no enhancement is observed. In parallel to the increasing mixing ratios, a change in the plume position and extension occurs. From May through August, the plume is expanding and moving northwest, whereas in September during the retreat of the monsoon the plume shifts southeast. Elevated mixing ratios are also observed for water vapor. Because of its short lifetime, advection in the free troposphere plays a less important role for water vapor, and its plume does not move northward but is stationary, extending up to $30^{\circ} \mathrm{N}$. Water vapor mixing ratios are anti-correlated with mixing ratios of $\mathrm{O}_{3}$, consistent with the concept that convective mixing moistens the upper troposphere and reduces $\mathrm{O}_{3}$.

The monsoon system over South Asia is associated with strong convective transport. At low altitudes, clean marine boundary layer air is transported towards the Asian landmass, and over the continent it is mixed with pollution. Trajectory calculations illustrate this transport of marine boundary layer air towards the Indian subcontinent followed by convective uplifting into the free troposphere. Air sampled in the northern part of the upper tropospheric anticyclone has generally traveled with the high altitude circulation for over one week, while trajectories for samples collected in the southern part of the anticyclone show recent ground contact, usually within the last four days prior to sampling. From the trajectory calculations it can be inferred that mainly emissions from India and the countries around the Bay of Bengal influence the measurements.
Based on the measured trace gas concentrations monthly emission rates of $\mathrm{CH}_{4}, \mathrm{~N}_{2} \mathrm{O}$, and $\mathrm{CO}$ and the net flux of $\mathrm{CO}_{2}$ in the monsoon region were estimated using $\mathrm{SF}_{6}$ as a reference gas. Measurements at the Mauna Loa observatory were used for background mixing ratios and the results were compared to emissions from the EDGAR database. On average, for $\mathrm{CH}_{4}$ and $\mathrm{CO}$, integration based emission estimates were lower than emission rates from the EDGAR database. For $\mathrm{N}_{2} \mathrm{O}$, a higher value was found. Keeping in mind the limitations of the approach, such as the usage of tracers from not co-located sources and that only a small part of the complete plume is probed, these results point to a possible underestimation of $\mathrm{SF}_{6}$ emissions in South Asia, an overestimation of $\mathrm{CH}_{4}$ emissions, or both. The difference found for $\mathrm{N}_{2} \mathrm{O}$ is insignificant and could indicate a seasonality in emissions not captured in the monthly mean emission rates derived from annual values in the database. The large difference found for $\mathrm{CO}$ remains puzzling. For $\mathrm{CO}_{2}$, a large net flux into the biosphere is found for which we have no corresponding literature value.

Another open question is the small-scale structure in the latitudinal distributions that may be related to the active and break phases of the monsoon. Besides the analysis for greenhouse gases, the CARIBIC samples are also analyzed for various non-methane hydrocarbons (Baker et al., 2010a) and halocarbons (O'Sullivan, 2007). Many of these compounds are short-lived and due to their different reaction rates with the $\mathrm{OH}$ radical can serve as photochemical "clocks". Extending the analysis to shorter-lived species may help to explain the structure of the plume structure in more detail. Of interest are for example the ages of air masses in different parts of the plume, and the $\mathrm{O}_{3}$ production/destruction potential of non-methane hydrocarbons.

Hitherto, CARIBIC provides the only regular multi tracer in-situ measurements in the monsoon plume. We hope that these data may serve as input for model comparisons or comparisons with satellite data and may help to better constrain emission estimates of the discussed greenhouse gases. In addition, it is hoped that in the future more in situ measurements of trace gases in the monsoon plume can be performed, including higher precision measurements of $\mathrm{SF}_{6}$, preferably on a regular basis.

Acknowledgements. We wish to thank all CARIBIC partners as well as Lufthansa, especially T. Dauer and A. Waibel, and Lufthansa Technik for their ongoing support. We especially acknowledge D. Scharffe for the operation of this complex platform and C. Koeppel for the handling of the whole air sampler. The GC system has initially been set up by D. Worthy and P. Bergamaschi, A. Jordan gave valuable advice on calibration issues. We thank J. Lelieveld for his helpful comments on the manuscript and T. Rhee for many fruitful discussions. The Mauna Loa data were provided by E. Dlugokencky, G. Dutton, T. Conway, P. Novelli from NOAA/ESRL. We acknowledge the support of the European Commission through the GEOmon (Global Earth Observation and Monitoring)Integrated Project under the 6th Framework Program 
(contract number FP6-2005-Global-4-036677). T. J. S. acknowledges the Paul Crutzen Nobelpreisträger-Stipendium granted by the Max-Planck-Society.

The service charges for this open access publication have been covered by the Max Planck Society.

Edited by: R. Ebinghaus

\section{References}

Akiyama, H., Yagi, K., and Yan, X.: Direct $\mathrm{N}_{2} \mathrm{O}$ emissions from rice paddy fields: Summary of available data, Global Biogeochem. Cy., 19, GB1005, doi:10.1029/2004GB002378, 2005.

Andreae, M. O. and Merlet, P.: Emission of Trace Gases and Aerosols From Biomass Burning, Global Biogeochem. Cy., 15, 955-966, doi:10.1029/2000GB001382, 2001.

Baker, A. K., Slemr, F., and Brenninkmeijer, C. A. M.: Analysis of non-methane hydrocarbons in air samples collected aboard the CARIBIC passenger aircraft, Atmos. Meas. Tech., 3, 311-321, 2010a, http://www.atmos-meas-tech.net/3/311/2010/.

Baker, A. K.: Characterization of non-methane hydrocarbons in Asian summer monsoon outflow observed by the CARIBIC aircraft, Atmos. Chem. Phys. Discuss., to be submitted, 2010b.

Bhat, G. and Narashima, N.: Indian summer monsoon experiments, Current Science, 93, 153-164, 2007.

Bogner, J. and Spokas, K.: Landfill $\mathrm{CH}_{4}$ : Rates, fates, and role in global carbon cycle, Chemosphere, 26, 369-386, doi:10.1016/ 0045-6535(93)90432-5, 1993.

Boos, W. R. and Kuang, Z.: Dominant control of the South Asian monsoon by orographic insulation versus plateau heating, Nature, 463, 218-222, doi:10.1038/nature08707, 2010.

Brenninkmeijer, C. A. M., Crutzen, P., Boumard, F., Dauer, T., Dix, B., Ebinghaus, R., Filippi, D., Fischer, H., Franke, H., Frie, U., Heintzenberg, J., Helleis, F., Hermann, M., Kock, H. H., Koeppel, C., Lelieveld, J., Leuenberger, M., Martinsson, B. G., Miemczyk, S., Moret, H. P., Nguyen, H. N., Nyfeler, P., Oram, D., O’Sullivan, D., Penkett, S., Platt, U., Pupek, M., Ramonet, M., Randa, B., Reichelt, M., Rhee, T. S., Rohwer, J., Rosenfeld, K., Scharffe, D., Schlager, H., Schumann, U., Slemr, F., Sprung, D., Stock, P., Thaler, R., Valentino, F., van Velthoven, P., Waibel, A., Wandel, A., Waschitschek, K., Wiedensohler, A., Xueref-Remy, I., Zahn, A., Zech, U., and Ziereis, H.: Civil Aircraft for the regular investigation of the atmosphere based on an instrumented container: The new CARIBIC system, Atmos. Chem. Phys., 7, 4953-4976, 2007,

http://www.atmos-chem-phys.net/7/4953/2007/.

Buchwitz, M., Schneising, O., Burrows, J. P., Bovensmann, H., Reuter, M., and Notholt, J.: First direct observation of the atmospheric $\mathrm{CO}_{2}$ year-to-year increase from space, Atmos. Chem. Phys., 7, 4249-4256, 2007a.

Buchwitz, M., Schneising, O., Burrows, J. P., Bovensmann, H., Reuter, M., and Notholt, J.: Corrigendum to "First direct observation of the atmospheric $\mathrm{CO}_{2}$ year-to-year increase from space", Atmos. Chem. Phys., 7, 5341-5342, $2007 \mathrm{~b}$.

Cai, Z., Xing, G., Yan, X., Xu, H., Tsuruta, H., Yagi, K., and Minami, K.: Methane and nitrous oxide emissions from rice paddy fields as affected by nitrogen fertilisers and water management, Plant Soil, 196, 7-14, doi:10.1023/A:1004263405020, 1997.
Chédin, A., Serrar, S., Scott, N. A., Crevoisier, C., and Armante, R.: First global measurement of midtropospheric $\mathrm{CO}_{2}$ from NOAA polar satellites: Tropical zone, J. Geophys. Res., 108, 4581, doi: 10.1029/2003JD003439, 2003.

Chen, P.: Isentropic cross-tropopause mass exchange in the extratropics, J. Geophys. Res., 100, 16661-16674, doi:10.1029/ 95JD01264, 1995.

Chen, Y.-H. and Prinn, R. G.: Estimation of atmospheric methane emissions between 1996 and 2001 using a three-dimensional global chemical transport model, J. Geophys. Res., 111, 10307, doi:10.1029/2005JD006058, 2006.

Conway, T., Lang, P., and Masarie, K.: Carbon Dioxide Dry Air Mole Fractions from the NOAA ESRL Carbon Cycle Cooperative Global Air Sampling Network, 1968-2008, Version: 200907-15, ftp://ftp.cmdl.noaa.gov/ccg/co2/flask/event/, 2009.

Crevoisier, C., Chédin, A., Matsueda, H., Machida, T., Armante, R., and Scott, N. A.: First year of upper tropospheric integrated content of $\mathrm{CO}_{2}$ from IASI hyperspectral infrared observations, Atmos. Chem. Phys., 9, 4797-4810, 2009, http://www.atmos-chem-phys.net/9/4797/2009/.

DeMore, W. B., Sander, S. P., Golden, D. M., Hampson, R. F., Kurylo, M. J., Howard, C. J., Ravishankara, A. R., Kolb, C. E., and Molina, M. J.: Chemical kinetics and photochemical data for use in stratospheric modeling, JPL Publication, 97-4, 1997.

Dlugokencky, E., Lang, P., and Masarie, K.: Atmospheric Methane Dry Air Mole Fractions from the NOAA ESRL Carbon Cycle Cooperative Global Air Sampling Network, 1983-2008, Version: 2009-06-18, ftp://ftp.cmdl.noaa.gov/ccg/ch4/flask/event/, 2009.

Dlugokencky, E. J., Steele, L. P., Lang, P. M., and Masarie, K. A.: The growth rate and distribution of atmospheric methane, J. Geophys. Res., 99, 17021-17044, doi:10.1029/94JD01245, 1994.

Dutton, G. S., Elkins, J. W., and Hall, B.: Nitrous Oxide $\mathrm{N}_{2} \mathrm{O}$ data from hourly in situ samples analyzed on a gas chromatograph located at Mauna Loa (MLO), Hawaii (19.539 N, 155.578 W, elevation: $3397 \mathrm{~m})$, ftp://ftp.cmdl.noaa.gov/hats/n2o/insituGCs/ CATS/monthly/, 2009.

Fu, R., Hu, Y., Wrigh, J. S., Jiang, J. H., Dickinson, R. E., Chen, M., Filipiak, M., Read, W. G., Waters, J. W., and Wu, D. L.: Short circuit of water vapor and polluted air to the global stratosphere by convective transport over the Tibetan Plateau, Proc. Natl. Acad. Sci. USA, 103, 5664-5669, doi:10.1073/pnas. 0601584103, 2006.

Fujinami, H. and Yasunari, T.: Submonthly Variability of Convection and Circulation over and around the Tibetan Plateau during the Boreal Summer, J. Meteor. Soc. Japan, 82, 1545-1564, 2004.

Gurk, C., Fischer, H., Hoor, P., Lawrence, M. G., Lelieveld, J., and Wernli, H.: Airborne in-situ measurements of vertical, seasonal and latitudinal distributions of carbon dioxide over Europe, Atmos. Chem. Phys., 8, 6395-6403, 2008, http://www.atmos-chem-phys.net/8/6395/2008/.

Hoskins, B. J. and Rodwell, M. J.: A Model of the Asian Summer Monsoon. Part I: The Global Scale., J. Atmos. Sci., 52, 13291340, doi:10.1175/1520-0469(1995)052, 1995.

Hsu, H.-H., Terng, C.-T., and Chen, C.-T.: Evolution of LargeScale Circulation and Heating during the First Transition of Asian Summer Monsoon., J. Climate, 12, 793-810, doi:10.1175/ 1520-0442(1999)012, 1999.

IMD: Southwest Monsoon 2008: End of Season Report, India Meteorological Department, New-Delhi, India, 2008. 
Joseph, P. V., Sooraj, K. P., and Rajan, C. K.: The summer monsoon onset process over South Asia and an objective method for the date of monsoon onset over Kerala, Int. J. Climatol., 26, 18711893, doi:10.1002/joc.134, 2006.

Kar, J., Bremer, H., Drummond, J. R., Rochon, Y. J., Jones, D. B. A., Nichitiu, F., Zou, J., Liu, J., Gille, J. C., Edwards, D. P., Deeter, M. N., Francis, G., Ziskin, D., and Warner, J.: Evidence of vertical transport of carbon monoxide from Measurements of Pollution in the Troposphere (MOPITT), Geophys. Res. Lett., 31, 23105, doi:10.1029/2004GL021128, 2004.

Khalil, M. A. K. and Butenhoff, C. L.: Spatial variability of methane emissions from rice fields and implications for experimental design, J. Geophys. Res., 113, G00A09, doi:10.1029/ 2007JG000517, 2008.

Krishnamurti, T. N. and Bhalme, H. N.: Oscillations of a Monsoon System. Part I. Observational Aspects., J. Atmos. Sci., 33, $1937-$ 1954, doi:10.1175/1520-0469(1976)033, 1976.

Krishnamurti, T. N., Jha, B., Rasch, P. J., and Ramanathan, V.: A High Resolution Global Reanalysis Highlighting the Winter Monsoon. Part I, Reanalysis Fields, Meteorol. Atmos. Phys., 64, 123-150, 1997.

Krishnamurti, T. N., Biswas, M. K., and Rao, D. V. B.: Vertical extension of the Tibetan high of the Asian summer monsoon, Tellus A, 60, 1038-1052, doi:10.1111/j.1600-0870.2008.00359. $\mathrm{x}, 2008$.

Lamb, B., McManus, J., Shorter, J., Kolb, C., Mosher, B., Harriss, R., Allwine, E., Blaha, D., Howard, T., Guenther, A., Lott, R., Siverson, R., Westburg, H., and Zimmerman, P.: Development of Atmospheric Tracer Methods To Measure Methane Emissions from Natural Gas Facilities and Urban Areas, Environ. Sci. Technol., 29, 1468-1479, doi:10.1021/es00006a007, 1995.

Lawrence, M. G., Rasch, P. J., von Kuhlmann, R., Williams, J., Fischer, H., de Reus, M., Lelieveld, J., Crutzen, P. J., Schultz, M., Stier, P., Huntrieser, H., Heland, J., Stohl, A., Forster, C., Elbern, H., Jakobs, H., and Dickerson, R. R.: Global chemical weather forecasts for field campaign planning: predictions and observations of large-scale features during MINOS, CONTRACE, and INDOEX, Atmos. Chem. Phys., 3, 267-289, 2003, http://www.atmos-chem-phys.net/3/267/2003/.

Lelieveld, J., Crutzen, P. J., Ramanathan, V., Andreae, M. O., Brenninkmeijer, C. A. M., Campos, T., Cass, G. R., Dickerson, R. R., Fischer, H., de Gouw, J. A., Hansel, A., Jefferson, A., Kley, D., de Laat, A. T. J., Lal, S., Lawrence, M. G., Lobert, J. M., Mayol-Bracero, O. L., Mitra, A. P., Novakov, T., Oltmans, S. J., Prather, K. A., Reiner, T., Rodhe, H., Scheeren, H. A., Sikka, D., and Williams, J.: The Indian Ocean Experiment: Widespread Air Pollution from South and Southeast Asia, Science, 291, 10311036, doi:10.1126/science.1057103, 2001.

Lelieveld, J., Berresheim, H., Borrmann, S., Crutzen, P. J., Dentener, F. J., Fischer, H., Feichter, J., Flatau, P. J., Heland, J., Holzinger, R., Korrmann, R., Lawrence, M. G., Levin, Z., Markowicz, K. M., Mihalopoulos, N., Minikin, A., Ramanathan, V., de Reus, M., Roelofs, G. J., Scheeren, H. A., Sciare, J., Schlager, H., Schultz, M., Siegmund, P., Steil, B., Stephanou, E. G., Stier, P., Traub, M., Warneke, C., Williams, J., and Ziereis, H.: Global Air Pollution Crossroads over the Mediterranean, Science, 298, 794-799, doi:10.1126/science.1075457, 2002.

Lelieveld, J., Brühl, C., Jöckel, P., Steil, B., Crutzen, P. J., Fischer, H., Giorgetta, M. A., Hoor, P., Lawrence, M. G., Sausen, R., and
Tost, H.: Stratospheric dryness: model simulations and satellite observations, Atmos. Chem. Phys., 7, 1313-1332, 2007, http://www.atmos-chem-phys.net/7/1313/2007/.

Li, Q., Jacob, D. J., Logan, J. A., Bey, I., Yantosca, R. M., Liu, H., Martin, R. V., Fiore, A. M., Field, B. D., Duncan, B. N., and Thouret, V.: A Tropospheric Ozone Maximum Over the Middle East, Geophys. Res. Lett., 28, 3235-3238, 2001.

Liu, J. J., Jones, D. B. A., Worden, J. R., Noone, D., Parrington, M., and Kar, J.: Analysis of the summertime buildup of tropospheric ozone abundances over the Middle East and North Africa as observed by the Tropospheric Emission Spectrometer instrument, J. Geophys. Res., 114, D05304, doi:10.1029/2008JD010993, 2009.

Liu, J. J., Jones, D. B. A., Worden, J. R., Noone, D., Parrington, M., and Kar, J.: Correction to "Analysis of the summertime buildup of tropospheric ozone abundances over the Middle East and North Africa as observed by the Tropospheric Emission Spectrometer Instrument", J. Geophys. Res., 114, 7399, doi: 10.1029/2009JD012045, 2009.

Liu, Y., Wang, Y., Liu, X., Cai, Z., and Chance, K.: Tibetan middle tropospheric ozone minimum in June discovered from GOME observations, Geophys. Res. Lett., 36, L05814, doi: 10.1029/2008GL037056, 2009.

Matsueda, H., Machida, T., Sawa, Y., Nakagawa, Y., Hirotani, K., Ikeda, H., Kondo, N., and Goto, K.: Evaluation of atmospheric $\mathrm{CO}_{2}$ measurements from new flask air sampling of JAL airliner observations, Pap. in Meteorol. Geophys., 59, 1-17, 2008.

Möllmann-Coers, M., Klemp, D., Mannschreck, K., and Slemr, F.: Determination of anthropogenic emissions in the Augsburg area by the source-tracer-ratio method, Atmos. Environ., 36, 95-107, doi:10.1016/S1352-2310(02)00212-1, 2002.

Morgan, C. G., Allen, M., Liang, M. C., Shia, R. L., Blake, G. A., and Yung, Y. L.: Isotopic fractionation of nitrous oxide in the stratosphere: Comparison between model and observations, J. Geophys. Res., 109, D04305, doi:10.1029/2003JD003402, 2004.

Mosier, A., Kroeze, C., Nevison, C., Oenema, O., Seitzinger, S., and van Cleemput, O.: Closing the global $\mathrm{N}_{2} \mathrm{O}$ budget: nitrous oxide emissions through the agricultural nitrogen cycle, Nutr. Cycl. Agrecosyst., 52, 225-248, doi:10.1023/A: $1009740530221,1998$.

Nishimura, S., Sawamoto, T., Akiyama, H., Sudo, S., and Yagi, K.: Methane and nitrous oxide emissions from a paddy field with Japanese conventional water management and fertilizer application, Global Biogeochem. Cy., 18, GB2017, doi:10.1029/ 2003GB002207, 2004.

Novelli, P. and Masarie, K.: Carbon Monoxide Dry Air Mole Fractions from the NOAA ESRL Carbon Cycle Cooperative Global Air Sampling Network, 1988-2008, Version: 2009-07-28, ftp: //ftp.cmdl.noaa.gov/ccg/co/flask/event/, 2009.

Olivier, J., Van Aardenne, J., Dentener, F., Pagliari, V., Ganzeveld, L., and Peters, J.: Recent trends in global greenhouse gas emissions: regional trends 1970-2000 and spatial distributionof key sources in 2000, J. Int. Environ. Sci., 2, 81-99, doi:10.1080/ $15693430500400345,2005$.

O'Sullivan, D. A.: Temporal and spatial variability of halogenated compounds and other trace gases, Ph.D. thesis, University of East Anglia, 2007.

Park, M., Randel, W. J., Kinnison, D. E., Garcia, R. R., and Choi, W.: Seasonal variation of methane, water vapor, and nitrogen oxides near the tropopause: Satellite observations and 
model simulations, J. Geophys. Res., 109, 3302, doi:10.1029/ 2003JD003706, 2004.

Park, M., Randel, W. J., Emmons, L. K., Bernath, P. F., Walker, K. A., and Boone, C. D.: Chemical isolation in the Asian monsoon anticyclone observed in Atmospheric Chemistry Experiment (ACE-FTS) data, Atmos. Chem. Phys., 8, 757-764, 2008, http://www.atmos-chem-phys.net/8/757/2008/.

Park, M., Randel, W. J., Emmons, L. K., and Livesey, N. J.: Transport pathways of carbon monoxide in the Asian summer monsoon diagnosed from Model of Ozone and Related Tracers (MOZART), J. Geophys. Res., 114, 08303, doi:10.1029/ 2008JD010621, 2009.

Randel, W. J. and Park, M.: Deep convective influence on the Asian summer monsoon anticyclone and associated tracer variability observed with Atmospheric Infrared Sounder (AIRS), J. Geophys. Res., 111, 12314, doi:10.1029/2005JD006490, 2006.

Randel, W. J., Park, M., Emmons, L., Kinnison, D., Bernath, P., Walker, K. A., Boone, C., and Pumphrey, H.: Asian Monsoon Transport of Pollution to the Stratosphere, Science, doi:10.1126/ science.1182274, 2010.

Randerson, J. T., van der Werf, G., Giglio, L., Collatz, G., and Kasibhatla, P.: Global Fire Emissions Database, Version 2 (GFEDv2.1), doi:10.3334/ORNLDAAC/849, 2007.

Sanjeeva Rao, P.: Arabian Sea Monsoon Experiment: An Overview, Mausam, 56, 1-6, 2005.

Scheele, M., Siegmund, P., and Velthoven, P. V.: Sensitivity of trajectories to data resolution and its dependence on the starting point: In or outside a tropopause fold, Meteorological Applications, 3, 267-273, doi:10.1002/met.5060030308, 1996.

Scheeren, H. A., Lelieveld, J., Roelofs, G. J., Williams, J., Fischer, H., de Reus, M., de Gouw, J. A., Warneke, C., Holzinger, R., Schlager, H., Klüpfel, T., Bolder, M., van der Veen, C., and Lawrence, M.: The impact of monsoon outflow from India and Southeast Asia in the upper troposphere over the eastern Mediterranean, Atmos. Chem. Phys., 3, 1589-1608, 2003, http://www.atmos-chem-phys.net/3/1589/2003/.

Schneising, O., Buchwitz, M., Burrows, J. P., Bovensmann, H., Reuter, M., Notholt, J., Macatangay, R., and Warneke, T.: Three years of greenhouse gas column-averaged dry air mole fractions retrieved from satellite - Part 1: Carbon dioxide, Atmos. Chem. Phys., 8, 3827-3853, 2008, http://www.atmos-chem-phys.net/8/3827/2008/.
Schneising, O., Buchwitz, M., Burrows, J. P., Bovensmann, H., Bergamaschi, P., and Peters, W.: Three years of greenhouse gas column-averaged dry air mole fractions retrieved from satellite Part 2: Methane, Atmos. Chem. Phys., 9, 443-465, 2009, http://www.atmos-chem-phys.net/9/443/2009/.

Schuck, T. J., Brenninkmeijer, C. A. M., Slemr, F., Xueref-Remy, I., and Zahn, A.: Greenhouse gas analysis of air samples collected onboard the CARIBIC passenger aircraft, Atmos. Meas. Tech., 2, 449-464, 2009, http://www.atmos-meas-tech.net/2/449/2009/.

Spivakovsky, C. M., Logan, J. A., Montzka, S. A., Balkanski, Y. J., Foreman-Fowler, M., Jones, D. B. A., Horowitz, L. W., Fusco, A. C., Brenninkmeijer, C. A. M., Prather, M. J., Wofsy, S. C., and McElroy, M. B.: Three-dimensional climatological distribution of tropospheric OH: Update and evaluation, J. Geophys. Res., 105, 8931-8980, doi:10.1029/1999JD901006, 2000.

Traub, M. and Lelieveld, J.: Cross-tropopause transport over the eastern Mediterranean, J. Geophys. Res., 108, 4712, doi:10. 1029/2003JD003754, 2003.

van Velthoven, P. F. J.: Meteorological analysis of CARIBIC by KNMI, http://www.knmi.nl/samenw/campaign_support/ CARIBIC/\#LH, 2009.

Wang, B., Ding, Q., and Joseph, P. V.: Objective Definition of the Indian Summer Monsoon Onset, J. Climate, 22, 3303-3316, doi: 10.1175/2008JCLI2675.1, 2009.

Worden, J., Jones, D. B. A., Liu, J., Parrington, M., Bowman, K., Stajner, I., Beer, R., Jiang, J., Thouret, V., Kulawik, S., Li, J.L. F., Verma, S., and Worden, H.: Observed vertical distribution of tropospheric ozone during the Asian summertime monsoon, J. Geophys. Res., 114, D13304, doi:10.1029/2008JD010560, 2009.

Xiong, X., Houweling, S., Wei, J., Maddy, E., Sun, F., and Barnet, C.: Methane plume over south Asia during the monsoon season: satellite observation and model simulation, Atmos. Chem. Phys., 9, 783-794, 2009,

http://www.atmos-chem-phys.net/9/783/2009/. 